\title{
KOVÁCS ESZTER*
}

\section{Klasszikus és kelet-európai diaszpóra- politikák. Tipologizálás ${ }^{1}$}

\begin{abstract}
tanulmány célja, hogy a klasszikusnak számító izraeli, ír és A örmény, valamint a kelet-közép-európai országok diaszpórapolitikáit megvizsgálja és elhelyezze Alan Gamlen diaszpórapolitikai tipológiarendszerében. A vizsgált esettanulmányok a jelenlegi magyar szakpolitika elemzéséhez szolgálhatnak adalékul.
\end{abstract}

\section{A diaszpórapolitika elméleti keretezései}

A diaszpórákat - elsősorban szociológiai szempontból - a hatvanas évek óta komolyan kutatják. A diaszpórapolitikák, vagyis az anyaország ezen csoportok megszólítására, megnyerésére, elkötelezésére (adott esetben akár a csoport „létrehozására”) irányuló törekvései csak az utóbbi 20-25 évben nyertek lendületet, majd ezzel párhuzamosan tudományos elemzések készültek ezekről az állami gyakorlatokról. Ez azzal magyarázható, hogy ebben az időszakban nemcsak a migrációs folyamatok gyorsultak fel jelentős mértékben, hanem a telekommunikáció is olyan fejlődésen ment keresztül, amely által a külföldre költöző és ott letelepedő személyek virtuálisan tagjai maradhatnak egykori anyaországuk társadalmának, vagyis a „transznacionális” életforma korábban ismeretlen minőségi szintre jutott, ami új helyzetet teremtett az anyaországi politikák

\footnotetext{
A szerző az MTA TK Kisebbségkutató Intézet munkatársa. E-mail: Kovacs.Eszter@tk.mta.hu.

${ }^{1}$ A tanulmány a Magyar diaszpórapolitika 1990 után az állam és a diaszpóra perspektívájából címü doktori értekezés 3 . fejezetének rövidített változata.
}

REGIO 26. évf. (2018) 3. szám 155-234. 
számára is. A vizsgált jelenségek újszerüségéből adódóan azonban a tudományterület némi deficittel küzd; ahogyan arra Délano és Gamlen rámutatnak, a diaszpórapolitikákra irányuló kutatások nagy hiányossága, hogy nélkülözik a megfelelö elméleti keretet. Ezek a kutatások ugyanis legtöbbször egy-egy (gyakorlatban létezö) diaszpórapolitika-modell elemzésére korlátozódnak, a modell „elhelyezéséhez”, összehasonlító értékeléséhez azonban nem áll rendelkezésre egy megfelelően használható, strukturált elméleti keret, tipológia. $^{2}$

Bár a nemzetközi diaszpórapolitikákkal foglalkozó szakirodalom sok esetben nem tesz különbséget a diaszpórák és a nemzeti kisebbségek között, és az anyaország ezen csoportokra irányuló politikáját is egységesen diaspora politics, esetleg kin-state politics ${ }^{3}$ címszó alatt elemzi, mégis érdemes a két csoportot különválasztani, legalább az olyan államok esetében, ahol mindkét csoport elég jelentős ahhoz, hogy külön eszközrendszer rendelődjön a rájuk irányuló kormányzati politikákhoz. A „történelmi” vagy nemzeti kisebbségek és a diaszpórák közötti különbségtételnél a migráció jelenti a határvonalat. A diaszpórák létrejötte ugyanis - bármilyen okú - migráció eredménye, míg a nemzeti kisebbségek határmódosítások, államok felbomlása következtében kerültek kisebbségi léthelyzetbe.

Ami a diaszpórapolitika definícióját illeti, a vizsgálat tárgyát képezi minden olyan kormányzati vagy kormányzati támogatást élvező kezdeményezés, program, intézmény, törvényi szabályozás, amely a diaszpóraközösség megszólítását, megnyerését, támogatását szolgálja. (Az angol nyelvü szakirodalomban a diaspora engagement policy vált a jelenséget leíró általános terminussá, ennek azonban nincs pontos magyar megfelelöje.)

$\mathrm{Az}$ elmúlt harminc évben a diaszpóraintézmények megsokszorozódását tapasztaltuk: míg a nyolcvanas években alig 30-40 állam rendelkezett olyan kormányzati intézménnyel, amely a diaszpórákat célzó állami programokat koordinálta, addig mára a

\footnotetext{
${ }^{2}$ Délano, Alexandra - Alan Gamlen: Comparing and Theorizing State-diaspora Relations. Political Geography, 41. 2014. July, 43-53.

3 A kin-state politics kifejezés kimondottan a „,történelmi”, határon túl élő nemzeti kisebbségekre irányuló anyaországi politikák megnevezésére használatos, amelyre magyarul a nemzetpolitika kifejezést használjuk.
}

REGIO 26. évf. (2018) 3. szám 155-234. 
világ országainak több mint fele müködtet ilyen szervet. ${ }^{4}$ Mi lehet a diaszpórák iránti megnövekedett érdeklődés magyarázata? Miért foglalkoznak az államok a külföldön élő diaszpórájukkal? Milyen megfontolások vezérelnek egy kormányt, hogy támogatást nyújtson olyan személyeknek, akik - bármilyen megfontolásból - elhagyták az anyaországot, és egy másik államban telepedtek le?

$\mathrm{Az}$ államok diaszpórájuk iránti érdeklödésének a szakirodalomban három elméleti magyarázatát találjuk. ${ }^{5} \mathrm{Az}$ első magyarázó keret a strukturális-instrumentalista elmélet, amely szerint az államok gazdasági helyzete magyarázza a diaszpórák iránti érdeklődést. Az elmélet a marxista világszemléletet tükröző wallersteini centrum-periféria gazdasági megközelítésből indul ki, és azt állítja, hogy a periféria országai törekednek a diaszpórák megszólítására, gazdasági hasznot remélve a velük való együttmüködéstől. Ez elsősorban a diaszpóra által hazaküldött megtakarításokat jelenti, azonban esetenként politikai haszonnal is járhat (szavazatszerzés, érdekérvényesítés a diaszpóra befogadó államában). ${ }^{6}$ Ezzel párhuzamosan a gazdag (centrum) államok nem érdekeltek a diaszpóra elkötelezésében. A diaszpórapolitikák strukturális-instrumentalista megközelítése tehát a közgazdaságtan és a nemzetközi gazdaságtan, illetve a fejlödéselméletek tudományterületének kereteibe illeszkedik, és lényegében gazdasági és nemzetközi pénzügyi folyamatokkal írja le és elemzi az anyaország és a diaszpóra között fennálló kapcsolatokat.

Az egyes országok diaszpórapolitikai gyakorlatát instrumentalista szemszögből megvizsgálva számtalan módját találjuk annak, hogy hogyan lehet a diaszpórával való együttmüködésből közvetlen vagy közvetett gazdasági előnyre szert tenni. A legegyértelmübb gazdasági előnynek a diaszpóra megtakarításainak hazautalásai (remittances) tekinthetőek. A hazautalások direktebb formáját jelentik az igen széles skálán mozgó befektetésösztönző programok, amelyek kifejezetten a diaszpóra számára kínálnak kedvező befektetési lehetőségeket az anyaországban, és így kölcsönösen

\footnotetext{
${ }^{4}$ Gamlen, Alan: Diaspora Institutions and Diaspora Governance. International Migration Review, 48, 2014. 1. 180-217.

${ }^{5}$ Ragazzi, Francesco: A Comparative Analysis of Diaspora Policies. Political Geography 41. 2014; Gamlen, 2014.

${ }^{6}$ Ragazzi, 2014.
}

REGIO 26. évf. (2018) 3. szám 155-234. 
előnyösek mind az anyaország, mind a diaszpóra számára. Szintén gyakorinak tekinthetőek az úgynevezett diaszpórakötvények. Ezeket az anyaországok kifejezetten az elvándorolt (adott esetben - például Izrael - a hazatérni nem kívánó) népesség számára bocsájtja ki, hogy máshol élve is hozzájárulhassanak az ország gazdasági fejlődéséhez. ${ }^{7}$ Instrumentalista eszköznek tekinthetők a különböző „expat adók”, vagyis a külföldön élö állampolgárokra kivetett változatos formájú bevételi formák. A diaszpóra bekapcsolása az anyaország fejlesztésébe nem csak közvetlen anyagi formában, hanem indirekt módon is megvalósulhat. Számos ország müködtet szakmai, tudományos, üzleti és egyéb csereprogramokat, amelyek egyrészt a diaszpóra és az anyaország szakértői csoportjai között kapcsolódási lehetőséget teremtenek, másrészt pedig teret nyitnak az innováció és a tudás szabadabb áramlása előtt. ${ }^{8}$

A strukturális-instrumentalista értelmezési keret meghatározó a szakirodalomban. A 2000-es évek elejétől a latin-amerikai és ázsiai országok diaszpórapolitikáinak vizsgálata egyértelmüen ebben az értelmezési keretben történik. ${ }^{9}$ Az elméleti keret dominanciáját erősíti az is, hogy a globális migrációval, illetve nemzetközi gazdasági és társadalmi folyamatokkal foglalkozó nemzetközi szervezetek is ebben a kontextusban foglalkoznak a diaszpórapolitikákkal. Az International Organization for Migration (IOM) 2012-ben jelentetett meg egy kézikönyvet, amelyben olyan jó gyakorlatokat foglaltak össze, amelyekkel az anyaországok hatékonyan tudják bevonni diaszpórájukat az ország gazdasági fejlődésének elősegítésébe. ${ }^{10}$ Bár a gazdasági várakozások kétségkívül meghatározóak az országok diaszpórapolitikájának alakításában, és a diaszpórapolitikák gazdasági racionalitással való

7 A diaszpórakötvényekkel az izraeli és az ír diaszpórapolitikát tárgyaló részekben részletesebben foglalkozom.

${ }^{8}$ Gamlen, Alan: Diaspora Engagement Policies: What Are They, and What Kinds of States Use Them? Centre on Migration, Policy and Society, Working Paper No.32. University of Oxford, 2006.

${ }^{9}$ A latin-amerikai országok fejlesztési célú diaszpórapolitikáiról magyar nyelven is született már doktori disszertáció, 1. Soltész Béla: Migráció és fejlesztő diaszpórapolitikák Latin-Amerikában. $\mathrm{PhD}$ disszertáció, Budapesti Corvinus Egyetem, 2016.

10 International Organization for Migration. Developing a Road Map for Engaging Diasporas in Development. International Organization for Migration, 2012.

REGIO 26. évf. (2018) 3. szám 155-234. 
magyarázata domináns a szakirodalomban, ${ }^{11}$ az elméletnek az az állítása, hogy a diaszpórájukkal csak a ,periféria” országai foglalkoznának, már meghaladottnak tekinthető. ${ }^{12}$

A második, diaszpórapolitikákat magyarázó elméleti keret az úgynevezett etnikai modell, amely a nacionalizmuselméletekből ismert etnikai nemzet koncepciójára épít. Ebben a megközelítésben az államok diaszpórapolitikája válasz a globalizáció és transznacionalizmus által a nemzetállamot ért kihívásokra; az államok a különböző diaszpórapolitikai eszközökkel kívánják az elvándorolt „nemzetrészeket” is ellenőrizni, kormányozni. Ennek megfelelően etnikai alapon kiterjesztik az állampolgárságot, valamint szociális, politikai és polgári jogokat is biztosítanak a lakóhellyel nem rendelkező állampolgáraiknak, végeredményben pedig, Anderson megfogalmazásával élve, „távolsági nacionalizmust" (long-distance nationalism) generálnak a diaszpóracsoportok körében. ${ }^{13}$

A diaszpórapolitikák vizsgálata ezen a ponton szorosan kapcsolódik a nacionalizmuselméletekhez. A nacionalizmuselméleteknek, azaz a nemzeti eszmével és a nemzetek eredetével foglalkozó tudományterületnek két nagy iskolája különböztethető meg: a primordialista (vagy perennialista) és a modernista. Nézőpontjuk különbözőségét nevük is mutatja: míg a primordialisták a nemzeteket öröktől fogva létező, de legalábbis etnikai alapokon, organikusan alakuló csoportoknak tekintik, amelyeknek a modernitás

${ }^{11}$ Østergaard-Nielsen, Eva, ed. International Migration and Sending Countries: Perceptions, Policies and Transnational Relations. 2003 edition. Houndmills, Basingstoke, Hampshire; New York: Palgrave Macmillan, 2003.; Lewitt, Peggy - Dehesa, Rafael de la: Transnational Migration and the Redefinition of the State: Variations and Explanations. Ethnic and Racial Studies, 26, 2003. 4. 587611.; Tiwari, Smita: Diaspora Engagement Policy in South Asia. In: Yong, Tan Tai - Rahman, Md Mizanur: Diaspora Engagement and Development in South Asia, International Political Economy Series. Palgrave Macmillan UK, 2013, 212-230.

12 Dufoix, Stéphane: From Nationals Abroad to 'Diaspora': The Rise and Progress of Extra-Territorial and Over-State Nations. Diaspora Studies, 4, 2011. 1-20; Gamlen, Alan: The Emigration State and the Modern Geopolitical Imagination.” Political Geography, 27, 2008. 8. 840-856., Gamlen, 2014.

13 Benedict, Anderson O'Gorman, Richard - Kligman, Gail: Long-Distance Nationalism: World Capitalism and the Rise of Identity Politics. Centre for Asian Studies Amsterdam, 1992.

REGIO 26. évf. (2018) 3. szám 155-234. 
előtt is megvoltak a kezdeményeik, ${ }^{14}$ addig a másik iskola szemlélete szerint a nemzetek modernista konstrukciók, nem szervesen fejlődött csoportok. Pontosabban fogalmazva a modernisták szerint a nemzetek nem is valós csoportok, hanem - Benedict Anderson kifejezésével élve - csupán ,elképzelt közösségek," 15 amelyek a modern kor vívmányai (egységes oktatás, nyomdakapitalizmus, a vallás társadalomszervező erejének meggyengülése ${ }^{16}$ ) által „képzelhetőek el”. A nacionalizmuselméletekben egyértelmüen a modernista megközelítés képviseli a mainstream iskolát. Ennek ellenére érdemes felhívni arra a figyelmet, hogy a diaszpórák vizsgálata kapcsán gyakran találkozunk a nemzet primordialista koncepciójához kötődő elemekkel; több szerző is ír arról, hogy a közös származás mítoszai, a nemzeti legendák igen fontos konstruáló erői a diaszpóráknak. ${ }^{17}$

A diaszpórapolitikák nacionalizmuselméleti magyarázata szerint az anyaországok azért foglalkoznak a diaszpórával, mert a nemzetet a nemzetállam határain kívül is fent kívánják tartani. A nacionalizmus eredeti, 19. századi formájában a nemzetállam megteremtésére törekedett, vagyis arra, hogy a nemzet és az állam határai megegyezzenek. A hidegháború végével ugyan bekövetkezett a nacionalizmus újraéledése, ez azonban számos ország esetében nem feltétlenül az államhatárok módosításának igényét jelentette, hanem a nacionalizmusnak egy új formáját. Ebben az új formában az állam a határokon kívül élő „,nemzetrészek” (nemzeti kisebbség,

\footnotetext{
${ }^{14}$ Smith, Anthony D.: Nationalism and Modernism. London: Routledge, 1998.

15 Anderson, Benedict: Imagined Communities: Reflections on the Origin and Spread of Nationalism. Verso, 1991.

${ }^{16}$ Hobsbawm, E. J.: Nations and Nationalism since 1780: Programme, Myth, Reality. Cambridge University Press, 2012; Gellner, Ernest: Nations and Nationalism. Cornell University Press, 2008.; Nairn, Tom: Faces of Nationalism: Janus Revisited. Verso, 1997.

${ }^{17}$ Sheffer, Gabriel: A Nation and Its Diaspora: A Re-Examination of Israeli-Jewish Diaspora Relations. Diaspora: A Journal of Transnational Studies, 11, 2011. 3. 331-358.; Smith, Anthony D.: Diasporas and the Homelands in History: The Case of the Classic Diasporas, In: Gal, Allon - Leoussi, Athena S. - Smith, Anthony D. (eds.): The Call of the Homeland: Diaspora Nationalisms, Past and Present, Leiden, Boston: Brill, 2010..; Safran, William: Israel and the Diaspora. Problems of Cognitive Dissonance. IMI Working Papers Series No. 53, Oxford Diasporas Programme. International Migration Institute, Oxford University, 2012.
}

REGIO 26. évf. (2018) 3. szám 155-234. 
vagy az elvándorolt diaszpóra) megtartására és reprodukálásra törekszik azáltal, hogy ezeket a csoportokat támogatja, elsősorban a folyamatot lehetővé tevő intézmények létrehozásával. A nacionalizmusnak ezt a formáját nevezi Csergő és James M. Goldgeir „transz-szuverén” nacionalizmusnak. ${ }^{18} \mathrm{~A}$,transz-szuverén” arra utal, hogy a nemzetállam túlterjeszkedik a hivatalos szuverenitásának keretein, hiszen az állam határain kívül élő népességre irányuló politikát folytat. Ugyanezt a fogalmat Pogonyi „transznacionális nacionalizmusnak" nevezi, ${ }^{19}$ utalva arra, hogy ez a fajta nacionalizmus a transznacionális keretek között definiálja újra a nemzeti eszme megvalósításának lehetőségeit. A transzszuverén vagy transznacionális nacionalizmus politikai gyakorlatának az az ideológiai legitimációja, hogy a nemzetnek akkor is integráns részeit képezik egyének (vagy csoportok), ha azok más államok állampolgárai; a nemzeti eszme tehát a nemzetállami kereteken túl is fenntartható. Ennek megfelelően az államok diaszpórapolitikájának motivációja az, hogy az elvándorolt egyének nemzeti identitását, származási országához való kötődését fenntartsák.
$\mathrm{Az}$ etnikai magyarázat szerint diaszpórapolitika kezdeményezésére azok az államok hajlamosak, amelyek a politikaival szemben az etnikai nemzetfelfogást alkalmazzák saját területükön belül is, vagyis a nemzet tagjait leszármazási/kulturális/nyelvi alapon, nem pedig lakóhely szerint, az állampolgári lojalitás alapján határozzák meg. Fontos azonban hangsúlyozni, hogy tisztán etnikai vagy tisztán polgári nemzetkoncepciót egy állam sem alkalmaz, hanem általában a kettő keveréke nyilvánul meg az állampolgársági szabályozásban. ${ }^{20}$

\footnotetext{
${ }^{18}$ Csergö, Zsuzsa - Goldgeir, James M.: Nationalist Strategies and European Integration. In: The Hungarian Status Law: Nation Building and/or Minority Protection, ed. Zoltán Kántor et al. Sapporo: Hokkaido University, Slavic Research Center, 2004.

19 Pogonyi Szabolcs: Four Patterns of Non-Resident Voting Rights. Ethnopolitics, 13, 2014. 122-40.

${ }^{20}$ Brubaker, Rogers: The Manichean Myth: Rethinking the Distinction Between 'Civic' and 'Ethnic' Nationalism," In: Nation and National Identity: The European Experience in Perspective, ed. Hanspeter Kriesi et al., Zurich: Ruegger, 1995. 55-71.; Lieblich, André - Bauböck, Rainer: Is There (Still) an East-West Divide in the Conception of Citizenship in Europe? Working Paper, 2010 ,
}

REGIO 26. évf. (2018) 3. szám 155-234. 
Ragazzi empirikus, kvantitatív kutatása a diaszpórapolitikák típusáról azt mutatta meg, hogy sem a strukturális-instrumentalista, sem az etnikai megközelítés nem ad megfelelö keretet a jelenség értelmezéséhez. Noha a diaszpóra megtakarításainak hazautalását megkönnyítő és szabályozó diaszpórapolitikákat magyarázhatja az első, azaz a marxista világszemléletű elmélet, arra nem ad választ, hogy miért adnak állampolgárságot, azzal együtt pedig különbözö jogokat az államok a lakóhellyel nem rendelkező diaszpóratagok számára. Ehhez hasonlóan az etnikai nemzetkoncepcióból kiinduló elméleti keret is elégtelennek bizonyul: ez a megközelítés ugyanis feltételezi, hogy az etnikai nemzetfelfogást képviselő államok inkluzív állampolgársági szabályozást alkalmaznak a területükön kívül élő diaszpóra irányában, azonban az eltérő nemzetiségü bevándorlók és azok gyermekei számára nem teszik lehetővé az állampolgárság megszerzését, hiszen a nemzetet etnikai-kulturális, nem lakóhely szerinti alapon definiálják. Az, hogy ez a feltételezés egyre kevesebb állam esetében igazolható, nemcsak Ragazzi kutatásából derül ki, hanem más, kifejezetten az állampolgársági politikákat vizsgáló kutatók munkáiból is. ${ }^{21}$ Alan Gamlen kutatásai pedig azt is megmutatták, hogy a diaszpórapolitikai gyakorlatok - a közvélekedéssel ellentétben - nem kizárólagosan az etnikai nemzetkoncepcióval bíró államok jellemzői. ${ }^{22}$

A két elmélet elégtelensége okán Ragazzi egy harmadik megközelítést javasol, amely megfelelöbb, egyben pontosabb keretet ad a diaszpórapolitikák okait feltárni kívánó összehasonlító kutatásokhoz. A harmadik elmélet a Foucault-tól származó „governmentality” koncepciójára épít, és azt állítja, hogy az államok diaszpórapolitikája a változó gazdasági-politikai körülményekre és érdekekre adott válasz, amely folyamatosan alakul. Nem beszélhetünk tehát statikus diaszpórapolitikákról, ellenben tudatosítanunk kell, hogy amit diaszpórapolitika névvel illetünk, az a nemzeti kormányok diaszpórájuk számára kidolgozott programjainak folyamatos módosítása, alakítása, amit a változó politikai és gazdasági helyzet indukál. ${ }^{23}$ Hasonló konklúzióra jut Alan Gamlen is, aki úgy fogalmaz: a diaszpórapolitikák általában nem egységes és

${ }^{21}$ Lieblich - Bauböck, 2010.

${ }^{22}$ Gamlen, 2006.

${ }^{23}$ Ragazzi, 2014.

REGIO 26. évf. (2018) 3. szám 155-234. 
koordinált állami szakpolitikát jelentenek, hanem „különböző időszakokban és különböző okokból megalkotott törvényi szabályozások és elindított programok konstellációját" (fordítás a szerzőtől), ezért a „politika” (policy értelemben) megnevezés nem is feltétlenül helyes. ${ }^{24}$ Mindez azonban nem jelenti azt, hogy értelmetlen lenne a diaszpórapolitikák összehasonlító vizsgálata, hiszen attól függetlenül, hogy az ebbe a fogalomkörbe tartozó konkrét állami intézkedések folyamatosan változnak és átalakulnak, léteznek olyan közös elemek, amelyek alapján tipológiákat lehet felállítani.

\section{A diaszpórapolitikák tipológiái}

A diaszpórapolitikák típusait számos kutató igyekezett már csoportosítani, így több szempont is rendelkezésünkre állhat, ami alapján a kategorizáció elvégezhető. ${ }^{25}$ Jelen tanulmányban Alan Gamlen tipológiarendszerét veszem alapul, mert ezt tartom kellően tágnak ahhoz, hogy a klasszikus modelleket, illetve a kelet-európai diaszpórapolitikai modelleket elhelyezhessük.

Gamlen vizsgálata 70 ország diaszpóra-,,engagement” gyakorlatára terjedt ki. ${ }^{26}$ A kutatás a minta alapján három nagy diaszpórapolitika-kategóriát azonosított be: a kapacitásépítő, a jogkiterjesztő, valamint a kötelezettségbehajtó modellt. A kapacitásépítés két pilléren valósul meg: a szimbolikus nemzetépítésen és az intézmények létrehozásán. Gamlen érvelésében az anyaország első lépésben retorikai szinten „hozza létre” a nemzeti diaszpórát, amely olyan lépésekből áll, mint az emigránsok nemzeti hősökként való emlegetése, szerepük hangsúlyozása a nemzeti függetlenség elnyerésében, illetve az anyaország ,paternalista” szerepvállalásában (a diaszpóráért vállalt felelösség hangoztatásában). A nemzeti identitás megkonstruálásában, illetve diaszpórára való kiterjesztésében a nyelvoktatási és kulturális programok, valamint a nemzeti nyelvü média támogatása is fontos szerepet tölt be. A

\footnotetext{
${ }^{24}$ Gamlen, 2006.

${ }^{25}$ Disszertációmban részletesen foglalkozom az egyéb lehetséges tipológiákkal, illetve 1.: Herner-Kovács Eszter: Elméleti keretek a diaszpóra-politikák vizsgálatához. Kisebbségkutatás, 2015/2. 34-39.

${ }^{26}$ Gamlen, 2006.
}

REGIO 26. évf. (2018) 3. szám 155-234. 
kapacitás-építés másik eleme, az intézmények létrehozatala azért szükséges, hogy a diaszpóra „kormányozhatóvá” váljék az anyaország által, vagyis míg a szimbolikus nemzetépítés „kommunikációs kapcsolatot” hoz létre, az intézmények az állam objektív kapacitását növelik. ${ }^{27}$ Erre a feladatra számos intézménytípus lehet alkalmas: a konzuli hálózat, a kifejezetten a diaszpórára koncentráló kormányzati szervek (minisztérium, államtitkárság, iroda, stb.), de akár a már létező diaszpóraintézmények is.

A jogkiterjesztési kategórián belül Gamlen két alcsoportot különböztet meg: a diaszpóra politikai inkorporációját, valamint a diaszpóra számára biztosított szociális és polgári jogokat. Előbbi nyilvánvalóan az állampolgárság diaszpórára történő kiterjesztésére vonatkozik, ami mögött számos motiváció húzódhat, melyek közül a leggyakoribb az, hogy a politikai közösségbe való bevonás „hízelgő” lehet a diaszpóra számára, ami miatt hajlamosabbak lesznek megtakarításaikkal és befektetéseikkel elösegíteni az anyaország gazdasági fejlődését. ${ }^{28}$ Gamlen ugyanakkor azt is kiemeli, hogy noha az állampolgárság megadása a diaszpóra számára bevett gyakorlatnak számít, a külföldi állampolgárok korlátozás nélküli szavazati joga már nem. Ahogy fogalmaz, az anyaországok próbálnak „takarékoskodni” a diaszpóra számára megadott jogokkal, ami megnyilvánulhat például abban, hogy a szavazati jogot csak belföldön gyakorolhatják. A polgári és szociális jogok kiterjesztésének gyakori formája a külföldön dolgozni kívánó állampolgárok ,kiközvetítése”, illetve a külföldön dolgozók védelme (például az egészségbiztosítás), adott esetben hazatelepülésük adminisztratív segítése.

Végül a diaszpórapolitikák harmadik csoportja, a kötelezettségeket behajtó modellek is két alcsoportra oszlanak Gamlen kutatásában: a diaszpórában rejlő gazdasági és a politikai jellegü erőforrások kiaknázására. Gamlen az előbbit „,befektetési politikáknak" nevezi, azonban célszerübb ezt a típust a tágabb értelmü gazdasági előnyöknek nevezni, hiszen nem csak a diaszpóra

${ }^{27}$ Uo. 10 .

28 Itzigsohn, Jose: Immigration and the Boundaries of Citizenship: The Institutions of Immigrants' Political Transnationalism. International Migration Review, 34, 2000. 4. 1126-1154.

REGIO 26. évf. (2018) 3. szám 155-234. 
anyaországban történő befektetésének ösztönzéséről van szó. Ebbe a kategóriába sorolható a „brain drain taxation”, vagyis a külföldön élő képzett munkaeröre kivetett adó (ami történhet hivatalos, de akár informális csatornákon keresztül is), a hazautalások és a befektetések ösztönzésére tett erőfeszítések (például a hazautalások pénzügyi tranzakciós költségének csökkentése), a „tudástranszfer” programok (a magasan képzett diaszpóra bevonása az anyaországi felsőoktatásba, szakmai programokba, innovációs kezdeményezésekbe).

A kötelezettségek behajtásának másik fö területe a politika, melynél elsősorban a diaszpórának az anyaország érdekében végzett lobbitevékenységét szokás érteni. Ez szintén történhet formális szinten (például az anyaország által - is - szponzorált lobbiintézmények mentén), de akár informálisan is, a diaszpóra helyi, illetve egyéni szinten történő szerepvállalása révén. A diaszpóra politikai erőforrásainak kiaknázása emellett a választójog kiterjesztése által is történhet. Az állampolgárságot a diaszpóra számára megadó kormányokkal kapcsolatban gyakori vád, hogy fó motivációjuk a szavazathalászat külföldröl. Valóban léteznek olyan „legendás” esetek, amikor a külföldön élö állampolgárok szavazatai döntöttek el egy-egy választást: Horvátországban a kilencvenes években a diaszpórában élök szavazati tartották hatalmon Franjo Tudjman pártját ${ }^{29}$; Romániában 2009-ben a külföldön élő románok fordították meg az elnökválasztás kimenetelét és ültették elnöki székbe Train Băsescut; Olaszországban pedig 2006-ban szintén a diaszpóra szavazatai döntött arról, hogy jobboldali kormánykoalíció alakult. ${ }^{30}$ Ezek az esetek azonban inkább a kivételt, semmint a szabályt jelentik, az államok többségében ugyanis a diaszpóraszavazatok nem szoktak döntőnek bizonyulni a választásokon. Egyrészt azért, mert a diaszpóra szavazati hajlandósága a legtöbb esetben jóval alacsonyabb a lakóhellyel rendelkező állampolgárokénál, másrészt pedig a kormányok meg tudják találni azt a szabályozási módot, amellyel a külföldön élők

${ }^{29}$ Winland, Daphne N.: We Are Now a Nation: Croats between "Home" and "Homeland. Anthropological Horizons, Toronto; Buffalo: University of Toronto Press, 2007.

30 Laguerre, Michel S.: Parliament and Diaspora in Europe. Europe in Transition: The NYU European Studies Series. New York: Palgrave Macmillan, 2013.

REGIO 26. évf. (2018) 3. szám 155-234. 
szavazati joga nem torzítja a választási eredményt. ${ }^{31}$ Gamlen kutatásának egyik konklúziója, hogy noha az állampolgárság diaszpórára történő kiterjesztése (,transznacionalizálása”) a vizsgált országok többségében megtörtént, a kötelezettségek behajtására még kevés kormány dolgozott ki hatékony eszközöket.

\section{Klasszikus diaszpórapolitikai modellek}

Elsőként áttekintem a legfontosabb diaszpórapolitikai modelleket. A klasszikusnak számító izraeli példa mellett a sokszor hivatkozott ír és örmény minta is elemzésre kerül, emellett egyes kelet-közép-európai diaszpórapolitikai modellek jellemzőit is felvázolom. Noha a görög diaszpóra történetisége miatt szintén klasszikusnak számít, mivel a kortárs görög diaszpórapolitika intenzitása nem kiemelkedő, illetve komparatív szempontból kevés relevanciával bír (összehasonlítva például az írrel vagy örménnyel), ezért ezzel nem foglalkozom.

$\mathrm{Az}$ esettanulmányomban három kérdést vizsgálok meg: a diaszpóra fejlődéstörténetének és - amennyiben releváns - az anyaországgal való viszonyrendszerének bemutatását, a diaszpórapolitika jogi és intézményi hátterét, valamint a diaszpórapolitika jellemző karakterét.

Izrael diaszpórapolitikája

A diaszpórák és diaszpórapolitikákkal kapcsolatos vizsgálatoknál megkerülhetetlen, hogy a klasszikus példát, a zsidó nép és Izrael állam kapcsolatának fejlődését megvizsgáljuk. Bár a zsidó nép évszázados szétszórattatás-története a diaszpóra fogalmától elválaszthatatlan, abból a szempontból mégis sajátságos esettel állunk szemben, hogy a diaszpóra léte megelőzte a modern nemzetállam létrejöttét.

A zsidó nép diaszpóraként való létezésének kezdőpontjának a babiloni fogságot (Kr.e. 597) szokás tekinteni. Találkozunk olyan értelmezéssel is, amely az asszírok általi üldöztetés időpontjától (Kr.

31 Bauböck, Rainer: Stakeholder Citizenship and Transnational Political Participation. A Normative Evaluation of External Voting. Fordham Law Review, 75, 2007. 5.

REGIO 26. évf. (2018) 3. szám 155-234. 
e. 700-as évek vége) datálják ${ }^{32}$ a zsidó nép szétszóratásának történetét, bár ezek az elüldözött közösségek nem maradtak fent tartósan. A babiloni fogság után az elüzött zsidó közösségek visszatértek Júdea területére, és többé-kevésbé önállóan kormányozták saját magukat a Római Birodalom térhódításáig, amikor a térség római provinciává vált. A zsidó nép második „szétszórattatása” 138-ban történt meg, amikor Hadrianus császár leromboltatta Jeruzsálemet, elüzve a területről a zsidó törzseket. A zsidó nép diaszporizációja valójában tehát ekkortól számítható, hiszen a népcsoport ókori „szülőföldjére” ezután már csak a modern Izrael állam megalapításakor térhetett vissza. Emiatt szokás 2000 éves zsidó diaszpóralétről beszélni.

A zsidó diaszpóra és Izrael állam kapcsolatában további sajátosságot hordoz a vallás szerepe, hiszen a konzervatív értelmezés szerint a zsidó tanítás az állam (újra)alakításáról is rendelkezik, méghozzá olyan módon, hogy a zsidó államot a szakralitás szférájába emeli. Vagyis, az ortodox zsidó hit szerint a zsidó állam nem lehet világi, politikai jelenség, azt csak a Messiás állíthatja helyre. Emiatt Izrael állam megalakítását bizonyos radikálisan konzervatív csoportok (például a Neturei Karta) a zsidóságon belül nem is fogadják el; azt bünösnek, Isten akarata elleni tettnek látják. ${ }^{33}$

Izrael és a diaszpóra kapcsolata az állam létrejötte óta rendkívül szoros, de a politikán belüli hangsúlyok dinamikusan változtak egyegy adott időszak kihívásaihoz alkalmazkodva. Izrael állam 1948-as megalakulása az évszázadok óta diaszpóralétben élő zsidóság számára egy teljesen új helyzetet teremtett, és természetesen a diaszpóra - állam viszonya kardinális kérdéssé vált rögtön az állam megalakulásakor. A viszonyrendszer megalapozása Izrael első miniszterelnöke, Ben Gurion és Jacob Blaustein, az egyik amerikai zsidó szervezet vezetője 1950-ben történt levélváltásával történt meg (Ben Gurion - Blaustein megállapodás). Ebben kimondták, hogy:

- az Amerikában élő zsidók politikai értelemben csak az Egyesült Államoknak tartoznak hüséggel;

32 The Diaspora, http://www.jewishvirtuallibrary.org/the-diaspora. (Utolsó letöltés: 2017. október 25.)

${ }^{33}$ What Is the Neturei Karta? http://www.nkusa.org/aboutus/ (Utolsó letöltés: 2017. október 25.)

REGIO 26. évf. (2018) 3. szám 155-234. 
- Izrael állam csak saját állampolgárait képviseli, a máshol élő zsidókat nem;

- az amerikai zsidók erejükből és befolyásukból fakadóan tanácsot adhatnak és segíthetik Izraelt, de nem beszélhetnek a nevében, és nem avatkozhatnak be a belügyekbe;

- noha kívánatos az Amerikában élő zsidók Izraelbe történő hazatelepülése, ez csakis az ő szabad akaratukból történhet. ${ }^{34}$

Az első miniszterelnök és az American Jewish Congress vezetője tehát kijelölte a diaszpóra és Izrael között fennálló kapcsolat alapelveit, amely a későbbi évtizedekben is meghatározta a viszonyrendszert. $\mathrm{Az}$ állam megalakulását követő években egyrészről biztosítani kellett a müködéshez szükséges, anyagi és egyéb feltételeket, másrészről pedig arra volt szükség, hogy az újonnan létrejött államot zsidó lakosság népesítse be. Az nem volt reális elképzelés, hogy a zsidó diaszpóra egésze alijázni fog, de természetesen a hazatelepülést elsődleges célként propagálta Izrael. A hazatelepülés ösztönzése mellett a diaszpórától érkező anyagi támogatás növelése, majd 1950-től ennek strukturális átalakítása következett a diaszpórakötvények formájában.

A diaszpórától Izraelbe (Izrael területére) folyósított anyagi támogatás az államalakulást jóval megelőzte. A pénztámogatások különféle zsidó szervezeteken, tipikusan a United Jewish Appealen (UJA) keresztül érkeztek, ahol a beérkezett támogatások 1948-ban érték el a rekordösszeget. Az UJA-n keresztül folyósított támogatások felhasználása kizárólag karitatív célokat szolgálhatott, ráadásul a szervezeti müködés miatt a felajánlott pénzek egy része nem is került a támogatandó területre. ${ }^{35}$ Részben ezeket az akadályokat is kiküszöbölendő, Ben Gurion 1950-ben bejelentette az amerikai zsidó diaszpóránál tett látogatásakor, hogy Izrael állam az eddigi jótékonysági adományok fogadása helyett strukturált és koordinált nemzetépítésbe kezd, amelyböl a diaszpóra is kiveheti a részét. Az új támogatási forma a diaszpórakötvény rendszere lett,

\footnotetext{
${ }^{34}$ Ben-Gurion-Israel and the Diaspora - The Ben-Gurion Blaustein Agreement http://www.zionism-israel.com/hdoc/Ben-Gurion-

Blaustein_Zionism_Diaspora.htm. (Utolsó letöltés: 2017. március 22.)

${ }^{35}$ Lainer-Vos, Dan: Manufacturing National Attachments: Gift-Giving, Market Exchange and the Construction of Irish and Zionist Diaspora Bonds. Theory and Society, 41, 2012. 1. 73-106.
}

REGIO 26. évf. (2018) 3. szám 155-234. 
amely egyszerre volt „ajándékozási” és befektetési lehetőség a diaszpóra számára.

A meghirdetéskor az amerikai zsidók több dolog miatt is aggodalmukat fejezték ki, például hogy milyen célokra fogja Izrael felhasználni a kölcsönt; a kötvényekkel valójában nem pénzt adnak az országnak, csak adósságterheit növelik; a UJA ezzel elveszíti bevételi forrását, ami akár az amerikai zsidó közösség szétforgácsolódását is magával hozhatja; végül tartottak attól is, hogy Amerikában kettős lojalitással fogják őket vádolni. Az aggodalmak miatt Ben Gurion egy új szervezetet alapított a kötvények kezelésére, az American Financial and Development Corporation for Israel-t, de az UJA-t ugyanakkor nem kerülte meg. Sőt, az új szervezet vezetői és a miniszterelnök maga is együttmüködést ígért az UJA-nak.

A diaszpórakötvények az államkötvényekhez nagyon hasonlóan müködtek (és müködnek ma is), néhány speciális szabályozás mellett. A megvásárolt kötvényeket három évig nem lehetett beváltani, azért, hogy az állam valóban hasznosan tudja forgatni a kölcsönt. Kereskedni nem lehet vele, ami a befektetönek nem kedvezö, emiatt viszont több kedvezményt is bevezettek. A kötvények kvázi életbiztosításként és utazási csekként is tudtak funkcionálni, ezzel az idősebb érdeklődőknek és az Izraelbe gyakran látogatóknak kedveztek. Végül azt is bevezették, hogy harmadik személy nevében is lehessen kötvényt vásárolni, így ajándékként is szolgálhatott az Izrael államnak adott kölcsön. Összességében természetesen nem mondható, hogy a diaszpórakötvény nagyon nagy hozamú, tehát pusztán pénzügyi racionalitásból nem érdemes ebbe fektetni. Viszont kiszámítható kamatozású volt, de mindenek előtt morális befektetés, hiszen megvásárlásával Izrael állam erősödését támogatta a befektetö, emellett azonban fontos volt, hogy nem pusztán ajándékról volt szó. ${ }^{36}$

Az izraeli kötvények összességében megduplázták a diaszpórától kapott pénzt az első pár évben, ezért az első szakasz lejárta után megújították a kibocsátást, és a mai napig lehetőség van izraeli diaszpórakötvények vásárlására. Ez rendkívül fontos volt amiatt, hogy valódi partnerségi kapcsolatot alapozott meg az állam és a diaszpóra között, hiszen nem csak ajándékot kértek a diaszpórától,

${ }^{36}$ Uo.

REGIO 26. évf. (2018) 3. szám 155-234. 
hanem hitet az izraeli államban és gazdaságban. A diaszpóra számára pedig fontos szimbolikus értéket jelentett, hogy az kötvényvásárlás kvázi alternatívája lett az alijázásnak, és a cionizmus egy új értelmezését és megvalósítását adta a diaszpóralétet választó zsidók számára.

A diaszpórától Izraelbe áramló anyagi támogatás az első 20-30 évben volt a legjelentősebb. A diaszpórakötvényeken kívül a különböző diaszpóraszervezeteken keresztül is áramoltak különböző célú pénzösszegek Izraelbe. Az 1967-es palesztin-izraeli háború azonban egészen konkrét választóvonalat jelentett a diaszpóraanyaország viszonyban, hiszen a viszonyrendszer struktúráját alapjaiban változtatta meg. Míg 1967 elött az állam létbiztonságának garantálása hatékonyan mobilizálta a diaszpóra zsidóságát, ${ }^{37} \mathrm{az}$ 1967-es győztes háború után a diaszpórában kialakult az a kép, hogy Izrael már életerős, önfenntartásra és önvédelemre képes állam. 1967 után jelentősen emelkedett az Izraelbe látogató turisták száma a diaszpórából, a hazatelepülések száma is megugrott egy időre, sőt, az adományok is kiugróan magas értéket értek el a háború évében és a következő pár évben. Emellett az 1967-es háborúra „értek be” azoknak a zsidó lobbi szervezeteknek a munkái is, amelyek az 1950-es években szerveződtek Amerikában, vagyis ekkor egy meglehetösen gyümölcsöző kapcsolat állt fent a diaszpóra és Izrael között.

A háború után azonban nagyon hirtelen változás állt be ebben a viszonyrendszerben. Egyrészről a diaszpóra zsidósága számára az antiszemitizmus egyre kevésbé volt napi szintü tapasztalat. A kulturális pluralizmus, a többes kötődések egyre inkább normává váltak a nyugati országokban, kiváltképp a számos diaszpóraközösségnek otthont adó Egyesült Államokban, ami a diaszpóralét (vélt vagy valós) fenyegetettségét, küzdelmes mivoltát jelentősen átformálta, normalizálta. Sheffer érvelésében ezek a változások azt eredményezték, hogy a zsidó diaszpóra elveszítette különös ismertetőjegyeit (üldöztetés tapasztalata, államnélküliség, vallás), és egyre inkább hasonlatossá vált a többi, állammal rendelkező diaszpórához. ${ }^{38}$

\footnotetext{
${ }^{37}$ Itt természetesen a jóléti államokban, biztonságban élő zsidó közösségekre kell gondolni, mindenekelőtt Észak-Amerikára és Nyugat-Európára.

${ }^{38}$ Sheffer, 2011.
}

REGIO 26. évf. (2018) 3. szám 155-234. 
Másrészről pedig Izrael nemzetközi pozíciója és megítélése is megváltozott, ami kihatott az állam és diaszpórája közötti viszonyra is. Az 1970-es évektől az izraeli külpolitikát, illetve a palesztin területekre történő telepítési politikát egyre többször illette nemzetközi kritika, amelyhez a zsidó diaszpóra liberális meggyőződésü tagjai is csatlakoztak. A diaszpóra Izraelnek biztosított anyagi és morális támogatása az 1990-es évekre látványosan megcsappant: míg az amerikai zsidó szervezetek által gyüjtött adományok tizenöt évvel korábban 65\%-ban Izraelbe kerültek, és csak 35\%-ukat használták fel a helyi zsidóság ügyeire, addig a kilencvenes évekre ez az arány 25:75 százalékra módosult, és a kétezres években is folytatódott az Izraelbe küldött adományok részarányának csökkenése. ${ }^{39}$

Mindeközben a diaszpóra zsidósága is sokat változott. A kilencvenes évekre az amerikai zsidó vezetőket aggodalommal töltötte el a diaszpóra asszimilációjának felgyorsulása, amelyet elsősorban az endogám házasságok számának erőteljes visszaszorulásával magyaráztak, kisebb mértékben a vallásosság és hagyományápolás népszerüségének csökkenésével, illetve a fiatalok közösségi életben való kevésbé aktív részvételével. ${ }^{40}$ A diaszpóra identitásának megerösítése emiatt kiemelt feladata lett Izraelnek. Leegyszerüsítve úgy is fogalmazhatunk, hogy ekkortól megfordult a támogatások iránya: míg az államépítés időszakában a diaszpóra támogatta, segélyezte Izraelt, a kilencvenes évektől az anyaország kezdi kulturálisan, identitáserősítésben támogatni a diaszpórát.

A diaszpóra identitásépítésének zászlóshajóprojektje az úgynevezett birthright program, amely 1999-ben indult Taglit Israel néven, és egy 10 napos ingyenes izraeli látogatást jelent a diaszpóra fiataljai számára. A program kigondolói szerint egy izraeli utazás nem pusztán az egyén zsidó identitását erősítheti meg, hanem a párválasztásra is kihathat, ${ }^{41}$ ezzel pedig lassíthat a diaszpóra

\footnotetext{
${ }^{39}$ Uo. 339.

${ }^{40}$ Saxe, Leonard - Chazan, Barry: Ten Days of Birthright Israel: A Journey in Young Adult Identity. Waltham, Mass: Hanover: Brandeis, 2008.

41 Több kutatás $(2009,2012,2013,2014)$ is vizsgálta, hogy a programon résztvevők hajlamosabbak-e zsidó partnerrel házasodni. Mindegyik felmérés azt mutatta meg, hogy míg a program résztvevői megközelítőleg 70\%-ban zsidó házastársat választanak, addig a programon nem résztvevők esetében ez az arány csak 50\% körüli. A 2014-es kutatás azt is megmutatta, hogy a programon
}

REGIO 26. évf. (2018) 3. szám 155-234. 
asszimilációs folyamatain. A programon az 1999-es indulás óta több mint 500 ezren vettek részt összesen 67 országból, ${ }^{42}$ a rövid- és középtávra vonatkozó vizsgálatok szerint pedig a program eredményesnek mondható a kitüzött célok elérésében is. Az izraeli mintát követve később több ország is elindította a saját birthright programját, természetesen a sajátos diaszpórapolitikai célokhoz igazítva az utazás tartalmát, fókuszát. Az izraeli birthright utazás is többközpontúvá vált, többféle profilú utazási és kapcsolódási lehetőségeket biztosítva a diaszpórának.

Az izraeli diaszpórapolitika intézményi és törvényi hátterével kapcsolatban mindenekelött azt fontos hangsúlyozni, hogy mivel a diaszpóralét megelőzte a modern államiságot, a diaszpórapolitika alakításában magának a diaszpórának legalább olyan szerepe van, mint az anyaországnak, és ez az intézményi háttérben is tetten érhető. Érdemes röviden áttekinteni a legfontosabb, diaszpóra által müködtetett, fenntartott vagy kezdeményezett szervezeteket - a teljesség igénye nélkül.

Izraelben 1929 óta létezik a Jewish Agency for Israel, amely eredetileg a diaszpórában élők Izraelbe történő települését hivatott segíteni, ily módon pedig rendkívül nagy szerepe volt az államalapítás folyamatában. A szervezet az államalakulást követően sem került állami tulajdonba, és a mai napig non-profit szervezetként müködik, Jeruzsálemben és Amerikában székel. Az alija gyakorlati segítésén túl egyéb módokon is kapcsolatot próbál teremteni Izrael állam és a diaszpóra között, például a különböző birthright utazások népszerüsítésével, civil kezdeményezések, szociális, kulturális és oktatási programok összefogásával. A szervezet szorosan együttmüködik a World Zionist Organization-nal, amelynek lényegében a végrehajtó szerve, és amely szintén az állam létrejötte előtt, még az 1897-es cionista világkongresszus alkalmával alakult meg, fó feladata pedig ma is a cionista eszme terjesztése a diaszpórában. A diaszpórában müködő főbb szervezetek közé sorolható még az American Joint Jewish Distribution Committee,

résztvevők 25\%-a egy másik Taglit résztvevővel házasodott. Saxe, Leonard et al. : Jewish Futures Project. The Impact of Taglit-Birthright Israel: Marriage and Family. Brandeis University, Maurice and Marilyn Cohen Center for Modern Jewish Studies, 2014. 14-15.

42 A Taglit Israel honlapja: http://www.birthrightisrael.com/about-uscontent?scroll=art_3 (Utolsó letöltés: 2016. szeptember 22.)

REGIO 26. évf. (2018) 3. szám 155-234. 
amely segélyprogramokat nyújt a zsidó közösségeknek szerte a világon az I. világháború óta. A szervezet székhelye New Yorkban található, innen történik a veszélybe került vagy rászoruló zsidó csoportok vagy egyének segítése. A szervezet együttmüködik az izraeli kormányokkal is: a hazatelepülő zsidók életkörülményeinek javításán, valamint betegápolásban, idősgondozásban segítenek. A Zsidó Világkongresszus (World Jewish Congress) szintén egy olyan diaszpóraszervezet, amely az állam létrejöttét megelőzően kezdte meg müködését, profilja a világon szétszórtan élő zsidó csoportok érdekképviselete, és az izraeli kormányoktól függetlenül müködik.

A diaszpórapolitikának az izraeli állami intézményrendszeren belül külön helye van. Érdekes módon a diaszpórával kapcsolatos kormányzati pozíció elöször csak 1999-ben jelent meg, a társadalmi ügyekkel összevontan (Minister for Social and Diaspora Affairs). 2003-ban miniszterhelyettesi pozícióként müködött tovább, majd 2006-ban ismét miniszteri szinten, összevontan a társadalmi ügyekért és az antiszemitizmus elleni harcért felelös tisztséggel (Minister for the Diaspora, Society, and Fight Against Antisemitism). 2009-ben a külügyek mellé rendelték a diaszpóraügyeket (Minister for Public Diplomacy and Diaspora Affairs), ezt követöen 2013-ban jött létre a Jeruzsálemért és a diaszpóraügyekért felelős miniszteri poszt (Minister for Jerusalem and Diaspora Affairs). A jelenlegi kormányban, 2015-től pedig kizárólag a diaszpóráért felelős miniszteri posztként (Minister of Diaspora Affairs) létezik a kormányzaton belül ez a felelősségi kör. ${ }^{43} \mathrm{Az}$ államalakulást követő első évtizedekben is létezett azonban olyan kormányzati egység, ami ugyan nem explicite, de mégis a diaszpórával foglalkozott, csak az akkori politikai céloknak megfelelő módon: az ötvenes évektől kezdve a diaszpóra ügye a bevándorlásügyi és „abszorpciós” miniszteri feladatkörön belül jelent meg. Jól mutatja ez az izraeli diaszpórapolitika történeti dinamikáját ahogy arra előbb utaltunk: míg az első évtizedekben a diaszpórában élők hazatelepítése és a tôlük való anyagi támogatás megnyerése volt a prioritás, a hetvenes évektől a „segélyezés” iránya megfordult, és a diaszpóra identitásának megerősítése, védelme került a fókuszba. Bár nem

${ }^{43}$ Governments of Israel, https://www.knesset.gov.il/govt/eng/GovtByNumber_eng.asp?govt=34. (Utolsó letöltés: 2017. március 24.)

REGIO 26. évf. (2018) 3. szám 155-234. 
kormányzati intézmény, de fontos megemlíteni, hiszen a diaszpórapolitikában fontos szimbolikus helyet foglal el az 1978 óta létező Diaszpóra Múzeum (Museum of the Jewish People) Tel Avivban. A múzeum a zsidó nép történetét meséli el, ezért a diaszpóra története is központi témája. 2005 óta törvény mondja ki, hogy a múzeum ,az izraeli és az egész világ zsidó közösségeinek nemzeti központja" ${ }^{4}$.

Izraelnek nincs klasszikus írott alkotmánya, hanem alaptörvények és egyéb jogi dokumentumok összessége adja az állam alkotmányos keretét. Az állam és a diaszpóra viszonyára vonatkozóan is létezik egy, az alaptörvények közé tartozó törvény, amelyet 1952-ben fogadott el az izraeli parlament, World Zionist Organization - Jewish Agency Status Law néven. A törvény azt mondja ki, hogy a világ zsidóságának képviselője a WZO és a Jewish Agency, valamint a diaszpórából való hazatelepülés felelösévé is ezt a két szervezetet nevezi meg. Emellett természetesen a Law of Return, vagyis az Izraelbe való bevándorlást és letelepedést szabályozó törvény is a diaszpóra jogállásáról rendelkező törvények közé sorolható. A törvény értelmében minden zsidó személynek joga van Izraelben letelepedni, és ezáltal automatikusan megkapja az izraeli állampolgárságot is. A zsidó „kategóriát” a törvény 1970-es módosításával kibővítették azokra is, akiknek csak egy nagyszülője zsidó, illetve aki zsidó személlyel kötött házasságot. Az izraeli állampolgárságnak kritériuma a hazatelepülés, vagyis a diaszpórában élők számára nem elérhető, ami a diaszpóra „kritikus tömegével” magyarázható. Izraeli állampolgár külföldön született gyermeke még megkapja az izraeli állampolgárságot, azonban a második generációra már nem terjed ki a származás útján történő állampolgárságszerzés joga.

Összefoglalásként elmondható, hogy Izrael állam megalakulásától kezdve az állam és a diaszpóra viszonya dinamikusan, az adott időszak politikai, társadalmi és gazdasági körülményei mentén változott. A diaszpórapolitikát az első évtizedekben - a gamleni tipológiát használva ${ }^{45}-$ kötele-

\footnotetext{
${ }^{44}$ Beit Hatfutsot - The Museum of The Jewish People. In Tel Aviv | About, Beit Hatfutsot, https://www.bh.org.il/about-us/about-beit-hatfutsot/. (Utolsó letöltés: 2017. november 28.)

${ }^{45}$ Gamlen, 2006.
}

REGIO 26. évf. (2018) 3. szám 155-234. 
zettségbehajtás jellemezte, azaz a diaszpóra minél teljesebb bevonása az államépítés folyamatába. Az elmúlt húsz-harminc évben azonban elmozdulás volt megfigyelhető a kapacitásépítés irányába, elsősorban a diaszpóra identitását erősítő programokon keresztül. Hangsúlyozni kell azonban, hogy a kötelezettség-behajtó aspektus továbbra is fontos része marad az izraeli diaszpórapolitikának, vagyis mindkét típusba egyaránt besorolható az eset.

Az, hogy a diaszpóra és az állam kapcsolatrendszere jól müködhessen, mindkét fél részéröl egyfajta kompromisszumot követelt meg. Safran úgy fogalmaz ezzel kapcsolatban, hogy a két fél „elfogadta egymás realitását”; a diaszpóra azt, hogy Izrael állam sem mentes a más államokra és társadalmakra jellemző problémáktól, Izrael pedig azt, hogy a diaszpóra az államiság megszerzését követően is központi szereplöje (vagy „helye”) a zsidó létnek. ${ }^{46} \mathrm{~A}$ partneri viszony a két fél között kulcsfontosságúnak bizonyult ahhoz, hogy az izraeli diaszpórapolitika eredményesen müködhessen.

\section{Írország diaszpórapolitikája}

Az ír diaszpórapolitika vizsgálatakor fontos szem előtt tartani azt a sajátosságot, hogy a diaszpórában élők száma többszörösét teszi ki Írország lakosságának: a hivatalos ír diaszpórastratégia adatai szerint az érintettek száma akár a 70 milliót is elérheti, ${ }^{47}$ míg az ország lakossága mindössze 6,4 millió. Nem meglepő tehát, hogy Írország rendelkezik az egyik legkimunkáltabb diaszpórapolitikával, amely alatt egyrészt egy nagyfokú transzparenciát, dokumentáltságot (aminek egyik legjobb forrása az ország hivatalos diaszpórastratégiája) kell érteni, illetve azt a tényt, hogy a diaszpórapolitika müködtetése az ír kormányzaton kívül a tudomány és a non-profit szektor által, a köztük lévő folyamatos együttműködéssel is erőteljesen megtámogatott. Azon túl, hogy létezik kormányzati szintủ felelős intézmény a diaszpórapolitika koordinálásra, egyéb fórumok (egyetemi tanszékek, civil

\footnotetext{
${ }^{46}$ Safran, 2012.

${ }^{47}$ Global Irish - Ireland's Diaspora Strategy (Department of Foreign Affairs and Trade, 2015).

https://www.dfa.ie/media/globalirish/global-irish-irelands-diaspora-policy.pdf 17.o. (Utolsó letöltés: 2017. szeptember 5.)
}

REGIO 26. évf. (2018) 3. szám 155-234. 
szervezetek, gazdasági társulások) is foglalkoznak az ír diaszpórapolitika különböző aspektusaival.

Az Írországból történő emigráció az ország történelmét végig kísérte. Noha az ír emigráció kezdőpontjaként legtöbbször az 18461852 között tartó Great Famine-t (a Nagy Éhínséget) szokás megnevezni, valójában már ezt megelőzően egymillió fölötti nagyságrendben hagyták el írek az ország területét. A 17 . és 18. század folyamán az ír migráció oka elsősorban a katolikus-protestáns ellentét volt, majd a 19. századtól a vallás helyett a sziget nehéz gazdasági helyzete vált az elvándorlás fő okává. ${ }^{48}$ A Nagy Éhínséget követő évtizedekben közel 2 millió ír vándorolt el az óhazából, többségük Amerikában telepedett le, ahol ennek következtében erős ír közösségek és hálózatok alakultak, ami a Great Famine lezárulta utáni évtizedekben is többmilliós ír emigrációt vonzott az Újvilágba. Amerika mellett Nagy-Britannia gazdagabb területei (Anglia, Skócia iparosodott városai) is fontos migrációs célpontnak számítottak az írek számára.

A független Írország létrejöttét (1920) követően hamarosan ismét intenzív elvándorlás vette kezdetét. Az 1950-es éveket az ír történelem „elveszett évtizedének” is nevezik, a népességfogyás ekkor a Nagy Éhínséghez hasonló mértékű volt. Az ötvenes évek kivándorlási hulláma főként a mezőgazdaságban dolgozó, fiatal, alacsonyan képzett íreket érintette. ${ }^{49}$ Ezt követően az 1980-as években volt újabb kivándorlási hullám érzékelhető; ekkor a magasan képzett, ám szintén fiatal népesség hagyta el az országot. A legújabb kivándorlási hullám a 2008-as gazdasági válságot követően vette kezdetét Írországban is, azonban esetükben jelentős a visszavándorlás mértéke. A 20. század során az Írországból történő migráció elsődleges célpontjává az Egyesült Királyság vált, azonban jelentős maradt az Egyesült Államokba történő kivándorlás is, kiváltképpen a nyolcvanas években. Emellett a legújabb, 2000-es évekbeli migráció célpontjai közé felkerültek közel-keleti és ázsiai országok, valamint Ausztrália és Kanada is. ${ }^{50}$

48 Gráda, Cormac Ó.: Ireland: A New Economic History, 1780-1939. Oxford: Clarendon Press, 1995.

${ }^{49}$ Keogh, Dermot - O'Shea, Finbarr - Quinlan, Carmel (eds.): The Lost Decade. Ireland in the 1950s. Cork: Mercier Press, 2004.

${ }^{50}$ Emigration Today| | EMIGRE: Current Irish Emigration and Return UCC, https://www.ucc.ie/en/emigre/emigration/. (Utolsó letöltés: 2017. október 26.)

REGIO 26. évf. (2018) 3. szám 155-234. 
A majdnem kétszáz éve tartó, lényegében folyamatosnak mondható kivándorlás miatt az ír diaszpóra meglehetősen heterogén. Ez a sokszínűség az ír diaszpórastratégia diaszpóradefiníciójában is tükröződik. A megfogalmazás ennek megfelelően tágan értelmezi, hogy kik a tagjai a diaszpórának: az ír emigránsok és leszármazottaik, valamint azok, akik Írországgal valós kapcsolatokat ápolnak. Utóbbi azt is jelenti, hogy nem feltétel az ír származás ahhoz, hogy valaki az ír diaszpórához tartozzon; a stratégia azt is az ír diaszpóra részének tekinti, aki külföldiként valamennyi ideig Írországban élt. Azt is hangsúlyozzák, hogy a diaszpóra nem „statikus”; az Írországhoz való kapcsolódás foka és mértéke különböző lehet, és egyénenként akár időben is változhat. A kapcsolódás mértékén kívül egyéb tekintetben is heterogén az ír diaszpóra: az emigrálás oka, az érdeklődési kör, az Írországról vallott elképzelések, a sikeresség mértéke az új országban stb. ${ }^{51}$

Intézményi szempontból az ír diaszpórapolitika felelőse a külügyminisztérium, azon belül 2002 óta létezik az Irish Abroad Unit, vagyis a külföldön élő írekkel foglalkozó főosztály. 2014 óta pedig létezik a diaszpóráért felelős miniszteri poszt (Minister of State for Diaspora Affairs) is, ami a magyar közigazgatásban tárca nélküli, leginkább államtitkári feladatkörnek feleltethető meg, jelen esetben megosztottan a miniszterelnöki és a külügyminisztériumi tárcák között. Az intézményi háttéren kívül fontos azt is látni, hogy az ír alkotmányban 1998 óta - a Nagypénteki Megállapodást követően szerepel kitétel az állam diaszpórához való viszonyáról, vagyis az ír diaszpórapolitikának van egy olyan megalapozása, ami mind szimbolikus, mind pragmatikus következményekkel jár. $\mathrm{Az}$ alkotmány 2. cikke úgy szól: „Az ír nemzet ápolja azon külföldön élő ír származású személyekkel való kapcsolatát, akik osztoznak az ír nemzet kulturális identitásában és örökségében." 52

Az ír diaszpórapolitika a függetlenség előtti időkig nyúlikvissza. Az 1850-es évektől bevettnek számított, hogy az ír politikusok az amerikai írek politikai és pénzügyi támogatását kérték a függetlenségi mozgalomhoz, azonban a 20. század elejére a diaszpóra már kellően önállósult ahhoz, hogy saját álláspontját

\footnotetext{
${ }^{51}$ Global Irish - Ireland's Diaspora Strategy, 16-17.

${ }^{52}$ Eredetiben: „The Irish nation cherishes its special affinity with people of Irish ancestry living abroad who share its cultural identity and heritage."
}

REGIO 26. évf. (2018) 3. szám 155-234. 
képviselje a függetlenséggel kapcsolatban. Bár az önálló Írország abszolút célként lebegett a diaszpóra szeme előtt is, annak amerikai elismertetéséig visszafogottabban kívántak ebben az ügyben politizálni, mint az anyaországi politikusok. A diaszpóra a függetlenség támogatására létre is hozta az Irish Victory Fund-ot, és mivel a diaszpóra úgy vélte, hogy a függetlenségi harcot elsősorban Amerikában kell „megnyerni”, az alapban összegyült pénzt nem akarták az ír kormánynak átadni. ${ }^{53}$

Ez a feszültség csak tovább nött az ír diaszpórakötvények kibocsátásával. Míg az izraeli esetben az 1950-es években a diaszpóra kötvények sikertörténetté váltak, az írek esetében ez a projekt teljes kudarccal zárult, és két év után meg is szüntették a kötvények kibocsátását. Noha az ír diaszpórakötvények konstrukciója ugyanazon az elven alapult, mint az izraeli, azaz egyidejűleg volt „ajándék” a diaszpórától az anyaországnak és befektetési lehetöség is, a kötvények kommunikációja és a kibocsátás kivitelezése nem sikerült jól. A kötvények ugyanis csak azután voltak beválthatóak, miután az ország függetlenségét nemzetközileg elismerték, ezáltal az ajándékjelleg dominánsabb volt a befektetésnél. A diaszpóra azt is nehezményezte, hogy a kötvények felhasználásába nem szólhatott bele. Az ellentétek olyan erőssé váltak, hogy az ír kormány a korábbi fő diaszpórapartnerszervezet megkerülésével létrehozott egy új diaszpóraszervezetet, amely a kötvények eladásával foglalkozott. Ez azonban legitimációs deficitje miatt nem tudta ellátni a feladatot, így 1922-ben befejezték a diaszpórakötvények kibocsátását. Ez tehát így a win-win szituáció helyett hatalmi harcot teremtett, illetve rávilágítottak a diaszpóra és az anyaország között meglévő távolságra és különbségekre. ${ }^{54}$

A legnépesebb ír diaszpóraközösség, az amerikai írek igen fontos szerepet játszottak az észak-ír konfliktus békés lezárásában. Az északír konfliktus már a hatvanas években elkezdődött, ám végleges megoldás a csak 1998-ban, a nagypénteki egyezménnyel született meg. A probléma három évtized alatt változó intenzitással, de folyamatosan jelen volt, eröszakos terrorakciókat is magában hordozva. A hatvanas évekre az amerikai írek már jól szervezett, civil szervezetekbe tömörülő diaszpórát alkottak, és azt a nézetet

${ }^{53}$ Lainer-Vos, 2012.

${ }^{54}$ Uo.

REGIO 26. évf. (2018) 3. szám 155-234. 
vallották, hogy Nagy-Britannia rosszhiszemüen beavatkozik Írország ügyeibe. A hetvenes években az amerikai írek már nyíltan támogatták az IRA fegyveres küzdelmét az Irish Northern Aid Committee-n keresztül. 1974-ben létrehozták az Irish National Caucus-t, azaz az ír kongresszusi lobbicsoportot is, amely nem katonai, hanem politikai téren igyekezett előmozdítani az ügyet, ír származású képviselőkkel és szenátorokkal együtt. Az amerikai ír lobbi taktikusan hallgatott az IRA akcióiról, és inkább arra alapozta stratégiáját, hogy a britek lépései ellen tiltakozzon. A lobbi sikeres volt abban, hogy kivívta az amerikai kongresszus és kormány támogatását az észak-írországi diszkriminációellenes elvek elfogadtatásához (vagyis implicite az írek helyzetének javításához), sőt magához a konfliktust lezáró megállapodás megkötéséhez is hozzájárult. ${ }^{55}$

Írország és a diaszpóra között tehát hosszú ideje léteztek kapcsolatok, de igazán strukturált diaszpórapolitika csak az utóbbi 20-25 évben kezdődött el. Koherens diaszpórastratégia pedig csak 2015-ben lett elfogadva. Az ír diaszpórastratégia felépítése a klasszikus stratégiai logikát követi: összefoglalja, hogy az elmúlt években-évtizedekben milyen főbb mérföldkövei voltak az ír diaszpórapolitikának; milyen aktuális kihívásokkal szembesül a szakterület; hol él és nagyjából mekkora az ír diaszpóra; valamint definiálja a stratégiai területeket, számba veszi, hogy melyek a létező eszközök ezek eléréséhez, és hol van szükség további beavatkozásra. A stratégia föbb területeiként a következőket határozza meg a dokumentum: támogatás, kapcsolattartás, elkötelezés (engagement), elismerés.

A stratégia legelöször is hivatkozik az ír alkotmány 2. cikkére, amely az ország diaszpórához való viszonyát definiálja, célként pedig egy „életerős, sokszínű globális ír közösséget” határoz meg, akik mind Írországgal, mind egymással kapcsolatban állnak. ${ }^{56} \mathrm{~A}$ „Kik alkotják az ír diaszpórát?” címü részben a dokumentum kimondja, hogy az ír diaszpóra tagjai a világszerte sokadik generációs ír migránsok leszármazottaiként élők is, de az országgal

\footnotetext{
${ }^{55}$ Cochrane, Feargal: Irish-America, the End of the IRA's Armed Struggle and the Utility of `Soft Power. Journal of Peace Research, 44, 2007. 2. 215-231.

56 Eredetiben: "Our vision is a vibrant, diverse global Irish community, connected to Ireland and to each other."
}

REGIO 26. évf. (2018) 3. szám 155-234. 
jelenleg kézzelfogható kapcsolatot ápoló, sőt, a nem ír származású, de az országgal valamilyen affinitást ápoló egyének is, vagyis egy tág diaszpóraértelmezésről van szó. A stratégia olyan diaszpórapolitikát jelöl ki célként, amely ennek a nagyon heterogén „diaszpórának” a lehető legtöbb tagját meg tudja szólítani, de kiemelt figyelmet kapnak azok az emigránsok is, akik új hazájukban támogatásra szorulnak. Ennek érdekében elsődleges cél, hogy az ír diaszpóráról naprakész tudása legyen a kormánynak, ezért a diaszpórakutatásokra szánt támogatások folyamatosak. ${ }^{57}$

Az ír diaszpóra anyagi támogatása lényegében egy kormányzati programon, az Emigrant Support Programme-on keresztül valósul meg, amiből évente több száz, külföldön müködő ír szervezet részesül. A támogatások pályázati formában valósulnak meg, és a támogatott projektek vagy kezdeményezések túlnyomó többsége jóléti jellegü, kisebb részük kulturális, a maradék pedig gazdasági jellegü. A stratégia rögtön a dokumentum elején leszögezi, hogy az ír diaszpórapolitika központi motívuma a külföldön élő írek jólétének elösegítése, így az, hogy a támogatások többsége szociális jellegü (például külföldön élő idős írek ellátása, egészségügyi támogatások), nem meglepő. A támogatások megítélésében a Külügyminisztériumon belül müködő Irish Abroad Unit az illetékes, de a döntéshozás az ír nagykövetségek és konzulátusokkal együttmüködésével történik.

Második pontként a stratégia a diaszpórával való kapcsolattartást irányozza elő. Ez a fejezet a leghosszabb a stratégián belül, hiszen nem csak a diaszpórával való kapcsolattartás intézményi hátteréről esik szó benne, hanem minden olyan programról és támogatási formáról, amelytől az ír kormány azt várja, hogy segíthetnek megerösíteni a kapcsolatot a diaszpórával. A fentebb említett külügyminisztériumi főosztályon és a diaszpóráért felelős miniszteren kívül létezik egy tárcaközi bizottság, amelynek minden olyan közigazgatási egység a tagja, amelyek valamilyen módon kapcsolatban állnak a diaszpórával, a diaszpórapolitikával. A kapcsolattartásnak három különböző színterét nevesíti a stratégia: a kommunikációt, a kultúrát, valamint a helyi kezdeményezéseket. Utóbbi kategória olyan programokat foglal magában, amelyek által az Írországból elszármazott diaszpóra a konkrét származási helyére

${ }^{57}$ Global Irish - Ireland's Diaspora Strategy. 17.

REGIO 26. évf. (2018) 3. szám 155-234. 
(városba, faluba) térhet vissza látogatóba. Ezekből a kezdeményezésekből 2013-ra egy országos szintü programsorozat is szerveződött „The Gathering” néven, amely a kapcsolattartás elősegítése mellett a turizmus fellendítésére is jótékony hatással volt. Hasonló kezdeményezésként az ír kormány támogatja az Ireland XO programot, amelynek keretében az ír plébániák és a diaszpóra kapcsolatának támogatása zajlik, családfakutatás céljából.

A kapcsolattartásnak kiemelt terepe a Global Irish Network, a világon élő, kb. 300 ír származású vagy írországi kötődésü „befolyásos személy” hálózata, amely az ír kormánnyal szorosan együttmüködve becsatornázza nemzetközi tapasztalatait olyan szakpolitikákba, mint a gazdaság, turizmusfejlesztés és kultúra. A Global Irish Networkhöz köthetőek olyan programok is, amelyek az ír diaszpórapolitika „engagement” területén kiemelten fontosak, például a Global Irish Economic Forum-ok. Emellett a Global Irish felületet biztosít kétoldalú tapasztalatcseréhez is: hasznos olyanoknak, akiknek a fogadó országbeli újrakezdéshez van szükségük tanácsokra, segítségre, és olyanoknak is, akik a hazatelepülésen, otthoni vállalkozásindításon gondolkoznak. A stratégia szerint a Network tagjainak rendszeres hírlevelet, valamint álláshirdetésekről szóló információkat fog küldeni a jövőben a külügyminisztérium.

Szintén a kommunikáció témaköréhez tartozik az ír tévé- és rádióadók vételének kiterjesztése, illetve online elérhetővé tétele. Fontos újítása a stratégiának, hogy olyan médiatámogatási alap létrehozását irányozza elö, amelyből a jelenkori emigrációval kapcsolatos hírek, élettörténetek megjelentetését lehet majd finanszírozni. A kapcsolattartás harmadik területének a kultúrát nevezi meg a dokumentum. Ezen a kategórián belül pedig az ősi ír (gaelic) nyelv oktatása, ír zenei- és táncfesztiválok támogatása, valamint kulturális intézetek és központok létrehozása/fenntartása jelenik meg elsődleges célként. A Szent Patrik nap és egyéb, ír nemzeti megemlékezések a kormány és a diaszpóra személyes kapcsolatfelvételének alkalmaiként szolgálnak. A kapcsolattartásnak van egy olyan oldala is, amely nem a diaszpóra közösségeiben, 
hanem Írországban valósul meg. Ennek markáns eleme a dublini Ír Emigráció Múzeuma, amely 2016-ban nyílt meg. ${ }^{58}$

$\mathrm{Az}$ ír diaszpóra stratégia „engagement” részében nagyon beszédes az, ahogy a fejezet kezdődik: „Partnerships”, azaz partnerségek. A diaszpóra megnyerését, elkötelezését szolgáló programok a köré az elképzelés köré épülnek, hogy Írország partneri viszonyban áll a diaszpórával; sok program esetében nem is az ír kormány a kezdeményező vagy a müködtető, hanem diaszpóraszervezetek, civilek vagy egyének. Az egyik bevezető gondolat is éppen arra mutat rá, hogy a diaszpórastratégia müködtetéséhez nem elég az ír kormány elkötelezettsége, hanem a diaszpóra önerejére is szükség van: „Az önkéntes szellem létfontosságú abban, hogy közösségi szervezetek százai müködhessenek világszerte, és nélkülözhetetlen ereje az aktív globális ír közösségnek is". ${ }^{59}$

A diaszpóra megszólítását célzó programok meghatározó része ebben a partnerségi szellemben müködik. A stratégiából kiderül, hogy az „engagement” politika homlokterében a globális ír hálózatépítés található. Nem titkolt célja az ír diaszpórapolitikának, hogy a hálózatosodás által a diaszpórában felhalmozott szakmai tudást és gazdasági erőforrásokat Írország javára fordítsa. A legtöbb projekt gazdasági együttmüködést, üzleti fórumot, hazai befektetést ösztönöz. Szinte kivétel nélkül alulról jövő kezdeményezésekről van szó, amelyek működtetésébe az ír kormány az Emigrant Support Program keretében kapcsolódik be, anyagi támogatás formájában. A programok között vannak klasszikus gazdasági hálózatosodást elösegítő kezdeményezések, mentorprogramok, de olyanok is, amelyek kreatív módon igyekeznek összekapcsolni a diaszpórát az anyaországgal. A ConnectIreland (amely szintén a Global Irish Network munkájának a gyümölcse) lényegében etnikai szolidaritáson alapuló befektetésösztönző program; azoknak a külföldön élő magánszemélyeknek, akik közvetítőként hozzájárulnak egy tengerentúli vállalkozás írországi terjeszkedéséhez, az újonnan

58 About EPIC Ireland | Dublin Docks Tourist Attraction, EPIC, http://epicchq.com/about-epic-irish-emigration-museum/. (Utolsó letöltés: 2017. október 26.)

59 Eredetiben: "The volunteer spirit is vital to keep hundreds of diverse community organisations going in all parts of the world and is a key strength of the active global Irish community."

REGIO 26. évf. (2018) 3. szám 155-234. 
teremtett írországi munkahelyek számától függően pénzjutalmat ad. Az engagement programok között találni még a hazatelepülést segítő kezdeményezéseket is, azonban ezek a gazdasági együttmüködést célzó programokhoz képest gyerekcipőben járnak.

A stratégia utolsó elemeként a diaszpóra elismerésének témaköre szerepel. Ebben a kategóriában leginkább a diaszpóra szimbolikus megszólítására, elismerésére létrehozott díjakról, kitüntetésekről van szó, érdekes azonban, hogy a kettős állampolgárság vagy a szavazati jog témaköre meg sincs említve sem ebben a fejezetben, sem a stratégia egészében. A diaszpóra elismerése tehát az ír esetben kifejezetten szimbolikus, nem politikai gesztusokat foglal magában. $\mathrm{Az}$ állampolgársághoz legközelebb álló elem az ír származási bizonyítvány (The Certificate of Irish Heritage), amely kifejezetten a sokadik generációs ír származású egyéneknek szól. Praktikus haszonnal nem jár, és mivel megszerzése nem jogi folyamat révén, hanem pénzért lehet kiállíttatni, jelentősége sokkal inkább szimbolikus, illetve a nemzeti márkázás (nation branding) szempontjából hasznos, hiszen olyan hírességek is rendelkeznek vele, mint Barack Obama vagy Bill Clinton.

A diaszpórapolitika fejlesztésére két irányt jelöl ki a stratégia: az új diaszpóraközösségek megtalálásában és programjaik támogatásában, valamint egy olyan alumni program kidolgozását, amelyben a világszerte Irországgal vagy ír tanulmányokkal foglalkozó öregdiákok vennének részt.

A mai ír diaszpórapolitika közel két évtizedes múltra tekint vissza. Írország a 19. század közepétől számított az amerikai írek politikai támogatására az ország függetlenségéért folytatott küzdelemben. Az anyaország és a diaszpóra kapcsolata, együttmüködése azonban nem volt mindig felhőtlen. Az állam önállósodását követően nem sokkal az északír konfliktus kezdte dominálni ezt a kapcsolatot, ami a konfliktus lezárultáig meghatározó maradt. Emiatt strukturált diaszpórapolitika csak az elmúlt húsz évet jellemezte, ez az időszak azonban nagyon sikeresnek mondható. A mai ír diaszpórapolitika középpontjában két dolog áll: a rászorulók támogatása, valamint a diaszpórában felhalmozott gazdasági és szakmai tudás közvetett becsatornázása Írország fejlesztésébe. Fontos kitétel, hogy „közvetett”, azaz nem direkt befektetések vagy hazautalások elvárásáról van szó (ahogy az a kudarcos diaszpóra kötvények idején történt), hanem a globális ír

REGIO 26. évf. (2018) 3. szám 155-234. 
diaszpórahálózattá szerveződéséből fakadó elönyökről. A diaszpórában rejlő potenciál kiaknázása minden projekt esetében partneri viszonyban, együttmüködésben valósul meg, és nagymértékben a diaszpóra kezdeményezéseire épül. Ahogy egy diaszpórapolitikai kutatási jelentés is írja: „Fontos leszögezni, hogy az Emigrant Support Program feladata a facilitálás, nem pedig a vezetés vagy az irányítás. A diaszpórapolitikák nemzetközi jó gyakorlatai is ezt a megközelítést támasztják alá, hiszen azt javasolják, hogy a diaszpóracsoportok önmaguk támogassák saját közösségeiket, a kormányok pedig alapvetően csak segítői legyenek a folyamatnak." ${ }^{\circ 0} \mathrm{Az}$ ír diaszpórapolitika mindemellett nyitott és befogadó a célközönség felé; nem húz éles etnikai vonalat a diaszpóra definíciójában, hanem kiterjeszti a diaszpóra értelmezését mindenkire, aki Î́rországhoz valamilyen módon kötődik.

A diaszpórapolitika gamleni tipológia rendszerében az ír modell - az izraelihez hasonlóan - egyszerre kapacitásépítő és kötelezettségbehajtó. A kötelezettségbehajtáshoz azt a kitételt érdemes hozzátenni, hogy az ír diaszpórapolitika sokkal inkább a közvetett „kötelezettségek” behajtására törekszik; közvetlen anyagi erőforrások helyett a diaszpóra szakértelmére, kapcsolati tőkéjére, kreativitására és proaktivitására támaszkodik.

\section{Örményország diaszpórapolitikája}

A diaszpóra klasszikus értelmezésének a zsidó és a görög mellett az örmény diaszpóra feleltethető meg. Az örmény népesség szétszóródása már a korai századokban megkezdődött a térséget érintő különböző vándormozgalmak, hódítások miatt, aminek eredményeként a 15. századra nagyszámú, föleg kereskedőkből és

${ }^{60}$ Kennedy, Liam - Lyes, Madeleine - Russell, Martin: Supporting the Next Generation of the Irish Diaspora, Report of a Research Project Funded by the Emigrant Support Programme, Department of Foreign Affairs and Trade. Dublin: Clinton Institute, University College Dublin, 2014.

https://www.dfa.ie/media/globalirish/Supporting-the-Next-Generation-of-theIrish-Diaspora.pdf. Eredetiben: "But it is important to state clearly that the role of the ESP should be to facilitate, not to lead nor direct. This approach is widely acknowledged as international best practice in diaspora engagement, which recommends that diasporic groups themselves must self-organise to support their communities, while governments act principally as facilitators."

REGIO 26. évf. (2018) 3. szám 155-234. 
értelmiségiekböl álló örmény közösségek vándoroltak el az etnikai magterületről Európa, Oroszország, de India irányába is. Ezt a korai örmény diaszpórát az 1915-1916-ban az Ifjú Törökök népirtása elől menekülö újabb menekülthullám „,frissítette fel”, és tette az örményt az egyik legaktívabb diaszpórává a világon. Ebben az értelemben az örmény népirtás jelenti a kezdőpontját a modern örmény diaszpóra kialakulásának. ${ }^{61}$ A népirtást követően a szovjet hatalomátvétel az 1920 körüli években újabb örmény menekültáradatot indított el, bár az az 1915-ösnél jóval szerényebb mértékü volt. Végül a Szovjetunió felbomlását és az ország függetlenedését követően indult be újból a migráció Örményország területéről, amelyet föként a gazdasági átalakulás nehézségei tápláltak.

Az örmény diaszpóra fejlődéstörténetének jelenlegi állapotában 6 milliós külföldi örmény népességről szokás beszélni, míg az ország mindössze 3 milliós. Az örmény diaszpóra legnépesebb csoportja Oroszország területén él, számukat 1,5-2 millió före becsülik. Az Amerikai Egyesült Államokban élő örmények száma ugyan számbelileg alacsonynak mondható (még fél millióra sem becsülik a számukat), ám aktivitásuk miatt az egyik legbefolyásosabb etnikai csoportként tartja őket számon a közvélemény. ${ }^{62}$ Százezer felettire becsülik a franciaországi, a grúziai és az ukrajnai örmény közösséget, és további több tízezres közösségek élnek különböző nyugat- és kelet-európai, valamint közel-keleti és kaukázusi államokban. Az örmény diaszpórafogalomban azonban különbséget tesznek a „belső” és a „külső” diaszpóra között. Belső diaszpóra alatt a volt szovjet tagköztársaságokban élő örményeket értik, akik javarészt a Szovjetunió időszaka alatt telepedtek le más tagköztársaságokban, föként munkavállalói célból - tehát a

61 Policy Forum Armenia: Armenia - Diaspora Relations: 20 Years Since Independence. (Policy Forum Armenia, 2010).

$62 \mathrm{Az}$ amerikai örmények valós lobbi erejének vizsgálata, elemzése a politológusok kedvelt témája, 1. pl: Panossian, Razmik: Between Ambivalence and Intrusion: Politics and Identity in Armenia-Diaspora Relations. Diaspora: A Journal of Transnational Studies, 7, 1998. 2. 149-96.; Koinova, Maria: Conditions and Timing of Moderate and Radical Diaspora Mobilization: Evidence from Conflict-Generated Diasporas. Global Migration and Transnational Politics Working Paper, 2009, no. 9; Zarifian, Julien: The Armenian-American Lobby and Its Impact on U.S. Foreign Policy. Society, 51, 2014. 5. 503-512.

REGIO 26. évf. (2018) 3. szám 155-234. 
legnépesebb, az oroszországi örmény diaszpóraközösség is ebbe a kategóriába tartozik. Ezzel szemben a külső diaszpóra az erőszakos atrocitások (első sorban a népirtás) elől menekülő örményeket és leszármazottaikat jelenti, akik föleg a Közel-Keleten és ÉszakAmerikában, illetve Nyugat-Európában telepedtek le. „Valódi” diaszpórának ez utóbbi típust tekintik az örmények, mert a klasszikus értelemben ők testesítik meg az üldözött, áldozati diaszpóracsoportot, akik identitásukat generációkon át megtartva kötődnek az óhazához, és annak boldogulásáért különböző eszközökkel tenni próbálnak. ${ }^{63}$

A zsidó diaszpórával tehát több ponton is párhuzamosságot mutat az örmény eset: a diaszpóra kialakulása több évszázaddal ezelött megkezdődött, és megelözte a modern államiságot; a modern diaszpóra identitását a népirtás emlékezete erősen befolyásolja; a diaszpóra népessége legalább akkora, mint az anyaországban élőké. Az Egyesült Államokban müködő aktív lobbiszervezeteik miatt szintén szokás a zsidó diaszpórához hasonlítani az örményt.

$\mathrm{Az}$ anyaország és a diaszpóra kapcsolata a függetlenséget megelőzően más szocialista országokhoz - köztük Magyarországhoz képest - intenzívebb volt, noha csak bizonyos megszorítások mellett igaz ez az állítás. A radikálisabb szervezetek, például a nacionalista Armenian Revolutionary Federation (Örmény Forradalmi Federáció) nem ismerte el a szovjet fennhatóság alá került Örményországot a nemzet legitim képviselőjének, és egészen a függetlenségig kizárólag a diaszpóraközösségek között, „emigrációban” müködött, majd 1991-ben visszatért Örményországba, és azóta politikai pártként parlamenti tevékenységet is folytat. Más külföldi örmény szervezetek viszont a szovjet időszak alatt is kapcsolatot tartottak Örményországgal, és 1964-ben a jereváni kormány felállította a diaszpórában élö örményekkel való kulturális kapcsolattartásért felelős bizottságot is. ${ }^{64} \mathrm{Az}$ örmény diaszpóra amerikai szervezetei a hetvenes évektől intenzív lobbitevékenységet végeztek, egyrészt az 1915-16-os események népirtásként való nemzetközi elismertetéséért, másrészt a független és egyesített Örményországért

63 Policy Forum Armenia, “Armenia - Diaspora Relations: 20 Years Since Independence."

${ }^{64}$ Uo.

REGIO 26. évf. (2018) 3. szám 155-234. 
(bár utóbbiért csak a radikálisabb Armenian National Committee of America - ANCA küzdött). ${ }^{65}$

Az ország függetlenedése után a népirtás elismertetéséért végzett lobbitevékenység nem szünt meg, de mellette az új helyzettel összefüggésben megjelentek egyéb célok is. Az önálló államiság müködésének támogatásához mindenekelőtt anyagi forrásokra volt szükség, így a nyugaton (föleg az USA-ban) élő örmény diaszpóra (kiváltképp az 1988-as földrengés okozta károk helyreállítása céljából) humanitárius segélyekért való lobbizással és közvetlen pénzügyi támogatások nyújtásával támogatta Örményországot. Szintén a függetlenedés éveire esett a karabahi háború, amely ismét mobilizálta az örmény diaszpórát: amellett, hogy a háborúvá forduló konfliktusban anyagilag támogatta Örményországot (Jereván erre a célra hozta létre 1992-ben a Hayastan Össz-Örményország Alapot), korlátozott számban a diaszpóra vezetői személyesen is részt vállaltak a harcokban, emellett pedig lobbierejüket is maximalizálták. A karabahi háború az ideológiai szempontból egyébként nem egységes amerikai örmény diaszpóraszervezeteket az ügy érdekében összefogásra tudta kényszeríteni, és az egyesített erő két fontos lobbieredményt is hozott számukra 1992-ben: az amerikai örmény szervezetek elérték, hogy az amerikai kongresszus két olyan törvényt (Humanitarian Aid Corridor Act és a Freedom Support Act Section 907) is elfogadott, amely a konfliktusban Örményországnak kedvezett Azerbajdzsánnal szemben. ${ }^{66}$

A karabahi háború meghatározó pontja volt a diaszpóra és Örményország közötti kapcsolat történetének. Korábban a két fél között csak korlátozottan létezett kapcsolat, sőt, a diaszpóra radikálisabb szárnya saját magát tekintette az örmény nemzet legitim képviselőjének a szovjet ralom alatt álló Örményországgal szemben. A függetlenség kivívása, az 1988-as természeti csapás és a karabahi háború egyértelmüen mozgásba hozta a korábban mérsékelt kapcsolatokat az anyaország és a diaszpóra között, viszont a politikai átalakulás nem hozott kiegyensúlyozott viszonyrendszert és harmonikus együttmüködést ebbe a kapcsolatba. A diaszpóra egyes,

${ }^{65}$ Gregg, Heather S.: Divided They Conquer: The Success of Armenian Ethnic Lobbies in the United States. Inter-University Committee on International Migration, 2002.

${ }^{66}$ Koinova, 2009.

REGIO 26. évf. (2018) 3. szám 155-234. 
mérsékeltebb szervezetei már a karabahi konfliktus alatt is, illetve azt követően is több ízben illették kritikával az örmény kormányt túlzott nacionalizmusa miatt, míg a radikális szervezetek épp ellenkezőleg, az Oroszországgal való jó viszonyra törekvése miatt a nemzeti érdek és szuverenitás feladásával vádolta az anyaországot. ${ }^{67}$ Örményország pedig azt veti a diaszpóra szemére, hogy még a legnagyobb szükségben, a karabahi háborúban sem nyújtott elég anyagi és politikai segítséget az anyaországnak. ${ }^{68}$

Annak érdekében, hogy az anyaország és a diaszpóra közötti viszony megfelelő mederbe terelődhessen, illetve a párbeszéd akadálytalan lehessen a két fél között, az örmény kormány 1999-től rendszeresen tart értekezleteket a diaszpóra képviselőivel. A diaszpórával való kapcsolattartásra a függetlenséget követő években a Külügyminisztérium lett kijelölve, amely a konferenciák mellett egyéb formális kapcsolattartási események (konferenciák, workshopok) megszervezéséért is felelt. 2008-ban a diaszpórapolitika önálló minisztériumot kapott, Diaszpóra Ügyek Minisztériuma néven. A kormányzaton belüli szervezeti megjelenésen túl az örmény diaszpórapolitikának egy másik fontos intézményesült egysége az 1992-ben létrehozott Hayastan Alap, amely a diaszpórától származó anyagi támogatások összegyüjtését és felhasználását koordinálja.

Bár a diaszpóra és az anyaország kapcsolata nem mentes a feszültségektől, a független Örményország nem mulasztotta el rögzíteni alkotmányában, hogy az országnak törekednie kell a diaszpórában élő örményekkel való kapcsolat előmozdítására, a külföldi örmény történelmi és kulturális értékek ápolására és a külföldi örmény oktatás és kultúra fejlesztésére. ${ }^{69}$ A diaszpóráért vállalt alkotmányos felelősségvállaláson kívül az állampolgárságot

${ }^{67}$ Uo.

68 Policy Forum Armenia, Armenia - Diaspora Relations: 20 Years Since Independence. 14-15.

${ }^{69}$ Within the framework of the principles and norms of the international law the Republic of Armenia shall contribute to fostering relations with the Armenian Diaspora, protecting the Armenian historical and cultural values located in other countries, advancing the Armenian education and culture" - Az Örmény Köztársaság Alkotmánya, 11. cikk.

http://www.parliament.am/parliament.php?id=constitution\&lang=eng

(Utolsó letöltés: 2017. április 26.)

REGIO 26. évf. (2018) 3. szám 155-234. 
szabályozó törvény vonatkoztatható még a diaszpórára, illetve bizonyos, főleg külpolitikai stratégiai dokumentumok foglalkoznak még a külföldön élö örményekkel, de ezek nem minősülnek jogi dokumentumoknak.

Az örmény parlament 2007-ben fogadta el azt a törvénymódosítást, amely lehetővé tette az örmény állampolgárság megszerzését a diaszpórában élő örmények számára. (Elötte népszavazáson döntöttek bizonyos alkotmánymódosítási kérdésekről, köztük a kettős állampolgárság lehetővé tételéről.) A módosítás lényege az, hogy az örmény felmenőkkel rendelkező, vagy korábban örmény állampolgársággal bíró, 18 . életévüket betöltött személyek örményországi lakóhely létesítése nélkül is az ország állampolgáraivá válhatnak. A szabályozást hosszú vita elözte meg, elsősorban amiatt, mert az esetleges tömeges állampolgárságszerzés politikai következményei beláthatatlanok voltak. Ennek a félelemnek lett az eredménye az a döntés, amely az állampolgársággal járó szavazati jog gyakorlását minimum három éven át tartó örményországi tartózkodáshoz kötötte - vagyis lényegében nem tette lehetővé, hogy a nem Örményországban élő örmények valóban szavazati jogot is szerezzenek. Az Örményország és a diaszpóra kapcsolatát értékelő 2010-es elemzés a törvényben rejlő nyilvánvaló korlátozás ellenére meglepőnek találja, hogy a diaszpórából meglehetősen alacsony az érdeklődés a kettős állampolgárság iránt. ${ }^{70}$ Mindebböl az a konklúzió vonható le, hogy bár papírforma szerint Örményország lehetővé teszi a diaszpóra számára a kettős állampolgárságot és a szavazati jogot, a gyakorlatban azonban csak az állampolgárság felvétele garantált a diaszpórában élők számára. Bár a kettős állampolgársággal nem feltétlenül kell együtt járnia a külföldön élők szavazati jogának, az örmény diaszpóra esetében úgy tünik, hogy önmagában az állampolgárság kis vonzerővel bír.

Mindazonáltal az a tény, hogy a diaszpóra és az anyaország kapcsolata nem teljesen nevezhető felhőtlennek, nem változtat azon, Örményország a függetlensége óta folyamatosan számít a diaszpóra segítségére. Annak érdekében, hogy a diaszpóra támogatása folyamatos maradjon és nőni tudjon, az ország számos területen tesz

70 Policy Forum Armenia, Armenia - Diaspora Relations: 20 Years Since Independence. 11.

REGIO 26. évf. (2018) 3. szám 155-234. 
fontos gesztusokat, „befektetéseket” is a diaszpórának. Az örmény diaszpórapolitika vizsgálatakor nem vonatkoztathatunk el attól, hogy egy, a függetlenségét frissen elnyert országról van szó, amelyik rögtön a függetlenségét követően háborúba lépett egyik szomszédjával, területi integritását folyamatosan kihívások érik, határvitái a mai napig sem rendeződtek. Ezekhez a külső fenyegetettséghez adódik hozzá az ország rossz gazdasági helyzete, végezetül pedig az örmény identitásban nagyon hangsúlyos szerepet betöltő 1915-ös népirtás emlékezete, amelynek nemzetközi elismertetése egy folyamatos cél, küldetés az ország külpolitikájában. A diaszpórapolitika alapértelmezett céljai tehát ezekből a körülményekből eredeztethetőek.

Mindenekelőtt tehát az ország megerősítése, stabilizálása, gazdasági fejlesztése a cél, amihez a diaszpóra hozzájárulását is elvárja Örményország. Mint arról fentebb már volt szó, a diaszpórától közvetlenül Örményországba küldött anyagi, fejlesztési segélyek az 1992-ben létrehozott Hayastan Alapon keresztül folynak be. Az anyagi segélyezés azonban csak egy lehetséges módja az ország fejlesztésének, egy másik nagyon fontos cél az ország „fizikai” megerősítése, és emiatt Örményország hangsúlyt fektet a diaszpórában élő örmények hazacsábítására. Ennek megvalósítása előbb a Külügyminisztérium, majd a Diaszpóra Ügyek Minisztériumának volt a felelőssége, 2012 óta pedig egy non-profit szervezet, a RePat Armenia foglalkozik a hazatelepülés gyakorlati segítésével. A RePat Armenia egyrészt népszerüsíti a hazatelepülés gondolatát a diaszpórában, a hazatelepedés mellett döntőknek segítséget nyújt az integrációban (lakhatás, munkakeresés, szakmai kapcsolatfelvétel, stb.), illetve szakmai anyagokkal igyekszik az örmény parlamentet segíteni abban, hogy hazatelepülésbarát jogi és politikai környezetet teremtsen. ${ }^{71}$

A diaszpóra fiatalabb tagjainak Örményország iránti figyelmének felkeltését szolgálja az örmény birthright program, a Birthright Armenia, ami a már korábban ismertetett izraeli program mintájára épül, de míg az izraeli program leginkább turisztikai körutazáshoz hasonlítható, addig az örmény program örményországi önkéntes munkára toborozza a külföldön élő örmény származású fiatalokat,

${ }^{71}$ Who We Are https://repatarmenia.org/en/about-us/who-we-are. (Utolsó letöltés: 2017. április 26.)

REGIO 26. évf. (2018) 3. szám 155-234. 
cserébe utazási költségtérítést, szállást és nyelvtanulást ajánl. A 25 év feletti érdeklődőknek 4 hetes szakmai gyakorlaton is lehetöségük van részt venni. ${ }^{72} \mathrm{~A}$ birthright program mellett számos egyéb, a diaszpóra nyelvi készségeit, kulturális önazonosságát és Örményországhoz való kapcsolódását fejleszteni kívánó program létezik. Szintén fontos gesztus a diaszpóra irányába a Virtuális Diaszpóra Múzeum, amely online tartalmakkal kívánja megismertetni az örmény diaszpóra történelmét, értékeit az egész örmény nemzettel. ${ }^{73}$

$\mathrm{Az}$ örmény diaszpórapolitika értékelése meglehetősen disszonáns. Egyrészről látható, hogy Örményország függetlenedése óta erőteljesen jelen volt a törekvés, hogy az ország építésébe és nemzetközi érdekeinek megvalósításába aktívan bevonják a diaszpóra közösségeit. Ennek érdekében intézményesült a diaszpórával való kapcsolattartás, és létrejöttek az együttműködés különböző fórumai. Ugyanakkor az is látható, hogy a diaszpórapolitika alakítása nem a diaszpórával való együttmüködésen és párbeszéden alapult, vagyis a kialakított intézményi kereteket nem sikerült megfelelően megtölteni tartalommal. Ezért a hiányosságért mindkét fél felelős. Örményország a diaszpóra egyértelmű igénye ellenére elzárkózott attól, hogy az állampolgárság jogi kötelékén túl effektív politikai részvételt is lehetővé tegyen az anyaország életében a diaszpóra számára. A diaszpórát pedig legtöbbször az a vád éri, hogy a rendelkezésére álló lehetőségeket sem ragadta meg, hogy hatékonyan segítse az örmény államépítést, és gyakran túl kritikus az anyaországi kormányokkal (emberi jogi kérdésekben és a korrupcióval kapcsolatban).

A diaszpóra szervezetileg nem eléggé fejlett, valamint rendkívül megosztott; ennek a helyzetnek az orvoslására viszont az anyaország tehetett volna az elmúlt 25 év folyamán hathatós segítségkísérletet. A Policy Forum Armenia elemzéséböl az az ellentmondás is kiolvasható, hogy noha intézményi szinten és a kommunikáció terén a diaszpóra és a diaszpórapolitika kiemelt jelentőséggel bír

\footnotetext{
${ }^{72}$ About the Program, Birthright Armenia, https://www.birthrightarmenia.org/en/faq. (Utolsó letöltés: 2017. április 26.) ${ }^{73}$ Armenian Diaspora Museum, http://armdiasporamuseum.com/. (Utolsó letöltés: 2017. április 26.)
}

REGIO 26. évf. (2018) 3. szám 155-234. 
Örményország számára, a valós tartalmi elemei látványosan hiányoznak egy hatékony szakpolitikához. Az elemzés rámutat például arra, hogy az örmény kormányok képtelenek voltak elöállni egy átfogó diaszpórastratégiával az elmúlt 25 év során, vagy pontosan kidolgozni, hogy a diaszpóra milyen konkrét segélyezési és befektetési lépésekkel tudná hatékonyan segíteni az országot. ${ }^{74}$

Az örmény diaszpórapolitika a gamleni kategóriarendszerben a kötelezettségbehajtó modellbe illik a leginkább. A kapacitásépítés és jogkiterjesztés egy-egy eleme is megjelenik, de a hangsúly a diaszpórában rejlő erőforrások kiaknázásán van. A bemutatott három diaszpórapolitikai modell közül az örmény kevésbé nevezhetö sikeresnek, aminek az izraeli és ír esettanulmányok alapján az lehet az oka, hogy nincs jól müködő partnerség az anyaország és a diaszpóra között, és ebből fakadóan a diaszpórapolitika kötelezettség-behajtó jellegét nem ellensúlyozza ki kellően az anyaország felől érkező kapacitásépítés (támogatás) vagy jogkiterjesztés.

A klasszikus diaszpórapolitikai modellek áttekintése rámutat egyrészt arra, hogy a diaszpórapolitikát érdemes történeti dimenziójában is elemezni, hiszen az anyaország és a diaszpóra kapcsolatának fordulópontjai hatással vannak a jelenlegi diaszpórapolitikára. Másrészről a klasszikus modellek áttekintése azt is megmutatta, hogy a gamleni hármas tipológiarendszer nem alkalmazható vegytiszta formában egyik esettanulmányra sem.

74 Policy Forum ArmeniaArmenia - Diaspora Relations: 20 Years Since Independence."

REGIO 26. évf. (2018) 3. szám 155-234. 
1.táblázat: Klasszikus diaszpórapolitikák a gamleni tipológiában

\begin{tabular}{|l|l|c|c|c|}
\hline $\begin{array}{l}\text { Típus } \\
\text { (Gamlen) }\end{array}$ & $\begin{array}{l}\text { Politikai } \\
\text { gyakorlat }\end{array}$ & Izrael & Írország & Örményország \\
\hline Kapacitásépítö & $\begin{array}{l}\text { Szimbolikus } \\
\text { nemzetépítés }\end{array}$ & + & + & + \\
\cline { 2 - 5 } & Intézmények & + & + & + \\
\hline Jogkiterjesztő & Állampolgárság & - & - & + \\
\cline { 2 - 5 } & Szavazati jog & - & - & - \\
\cline { 2 - 5 } & $\begin{array}{l}\text { Polgári és } \\
\text { szociális jogok }\end{array}$ & - & + & - \\
\hline \multirow{2}{*}{$\begin{array}{l}\text { Kötelezettség- } \\
\text { behajtó }\end{array}$} & $\begin{array}{l}\text { Befektetés- } \\
\text { ösztönzés }\end{array}$ & + & + & + \\
\cline { 2 - 5 } & Network & - & + & + \\
\cline { 2 - 5 } & Lobbi & + & - & + \\
\hline
\end{tabular}

\section{Kelet-közép-európai diaszpórapolitikák}

A klasszikus esttanulmányok mellett érdemes kelet-középeurópai regionális kitekintést is tenni a diaszpórapolitikák típusairól. A posztszocialista országok diaszpórapolitikáinak vizsgálatakor számos hasonlóság fedezhető fel, ugyanakkor az is megállapítható, hogy nem beszélhetünk egyértelmüen egységes közép-európai diaszpórapolitikai modellről. A régió országai a részben hasonló, részben összefonódott történelmük miatt számos hasonlósággal bírnak, ami evidens módon a diaszpóra fejlődéstörténetére is hatással van. Az azonban, hogy az egyes országok milyen megfontolásból, milyen cél- és eszközrendszerrel viszonyulnak a diaszpórájukhoz, már jóval differenciáltabb.

A vizsgálat kiindulópontjának tehát azt tekinthetjük, hogy a posztszocialista országok diaszpóráinak karaktere meglehetősen hasonló. A kelet-európai diaszpórák történeti fejlődése nagymértékben hasonlít a magyar diaszpóra fejlődéstörténetére. Az első meghatározó emigrációs hullám a 19. század végi „parasztexodus” volt, amely a térség országait egyformán érintette, 
azaz föként a szegényebb, paraszti rétegeket vonzotta elsősorban Amerikába, kisebb mértékben Kanadába és a latin-amerikai országokba. Az I. és kiváltképp a II. világháború kelet-európai politikai menekültjei a tengerentúlon és Nyugat-Európában kerestek menedéket. A kommunista évtizedek alatt már jobban szétválik a kelet-európai országok kivándorlás-története: míg Magyarországról az 1956-os forradalmat követően tetőzött az elvándorlás, addig Lengyelország esetében a hatvanas évek első felében, Románia, Csehszlovákia és Jugoszlávia esetében pedig a hetvenes-nyolcvanas években. ${ }^{75}$

A rendszerváltások, illetve Csehszlovákia és Jugoszlávia esetében az államszövetségek felbomlása egy teljesen új helyzetet teremtett a kelet-európai migrációs trendekben. A háborús Jugoszlávia területéről egy új emigrációs hullám indult meg, amely a nyugaton élő diaszpóra közösségeihez részben csatlakozott. A romániai forradalom szintén nagymértékü elvándorlást eredményezett a kilencvenes évek első éveiben. Csehszlovákia felbomlása az egykori államszövetségen belüli népességmozgást indukált. A magyarországi demokratikus átmenet ugyan szintén utat nyitott a szabad kivándorlásnak, de ennek a mértéke a román és a jugoszláv példákhoz képest sokkal kisebb volt, ráadásul a szomszédos országokból (különösen Romániából) megindult az ott élő magyarok Magyarországra történő vándorlása, ami pedig migrációs nyereséget jelentett. ${ }^{76}$

A posztszocialista kelet-európai országok esetében a demokratikus átalakulás a diaszpórához való viszonyrendszerben egy fontos választóvonalnak tekinthető . A kommunizmus évei alatt ugyanis a külföldre emigráltakkal ezek az országok csak korlátozottan tartottak kapcsolatot, egyes esetekben és bizonyos időszakokban pedig kifejezetten ellenséges volt a viszony az antikommunista emigráció és az országot vezető kommunista

75 Puskás Julianna USA-ra vonatkozó táblázatai alapján. L. Puskás, Julianna: Migráció Kelet-Közép-Európában a 19. és 20. században. Regio, 1991. 4. 22-48. 76 Tóth Pál Péter. "Nemzetközi vándorlás - Magyarország (1990-2000)." Népesedési Kormánybizottság Migrációs Bizottsága 2002. programja, KSH Népességtudományi Kutatóintézet.

http://kisebbsegkutato.tk.mta.hu/kettosallampolgarsag/tanulmanyok/nemzetkoziv andorlas_mo.pdf

REGIO 26. évf. (2018) 3. szám 155-234. 
kormányok között. A rendszerváltások tehát bizonyos szempontból az anyaországok számára megteremtették a lehetőségét annak, hogy a diaszpóra irányába jóvátegyék a múlt sérelmeit, és „visszaemeljék” a korábban elvándorolt személyeket a nemzet közösségébe.

A kelet-európai országok esetében azonban nem csak a diaszpórában élő „nemzetrészek” kerültek vagy kerülhettek elötérbe 1990 után, hanem a határon túli kisebbségek is, amelyek a 20. századi határmódosulások vagy éppen az 1990 utáni államszövetségek felbomlása eredményeként kerültek az anyaország határain kívülre. Amint látni fogjuk, a kelet-európai országok ezzel a kétféle külföldön élö kisebbséggel a legtöbb esetben egyszerre és ugyanabban a jogszabályi és intézményi keretrendszerben kezdtek el foglalkozni, azonban a hangsúlyok és prioritások eltérőek az egyes országok esetében.

$\mathrm{Az}$ összehasonlíthatóság érdekében az egyes országokat azonos szempontok szerint elemzem. Megvizsgálom a törvényi keretet: létezik-e alkotmányos felelősségvállalás, ha igen, abban hogyan jelenik meg a diaszpóra; létezik-e kedvezmény- és/vagy státustörvény a külföldön élö „nemzettagokra” vonatkozóan; elérhetö-e valamilyen stratégiai keret a diaszpórával kapcsolatban; van-e állampolgársági és választójogi vonatkozása a diaszpórapolitikának. A törvényi keret mellett a diaszpórapolitika intézményi (közigazgatási felelősségi terület, egyeztető fórum) vonatkozásait, valamint a konkrét támogatási, együttmüködési programokat is vizsgálom. A könnyebb áttekinthetőség érdekében elöször országonként veszem sorra a vizsgálandó pontokat, végül egy komparatív összefoglalóját adom a tárgyaltaknak.

Horvátország

A horvát diaszpóra fejlődéstörténete az 1950-es évekig lényegében tükrözi a magyarét. A II. világháborút követően egy nagyon erősen antikommunista beállítottságú horvát emigráció alakult ki és szervezte meg magát, a legkoncentráltabban Torontóban, Kanadában, de természetesen az Egyesült Államokban is. Ez a politikailag aktív, jobboldali beállítottságú társaság nagyon eltért a korábbi, inkább szocialista beállítottságú horvátoktól. Az 1960-as évektöl emigrálók már centristák vagy mérsékelten jobboldaliak voltak, de közel sem annyira antikommunisták, mint az 
1945-ösök. Jugoszlávia széthullásakor tehát egy ideológiailag megosztott horvát diaszpórával bírt Horvátország, amelynek a nacionalista köreivel a Horvát Demokratikus Párt (HDZ) vezetősége tudatosan azonnal nagyon szoros kapcsolatot épített ki. ${ }^{77}$

Az, hogy a HDZ egyértelmüvé tette, hogy az új ország a horvát nemzet állama lesz, függetlenül a horvátok lakóhelyétől, a diaszpóra politikailag mérsékeltebb köreit is hatásosan tudta mozgósítani. Ennek eredményeként a horvát diaszpóra mind a háborús harcok finanszírozásában, mind a függetlenségért folytatott nemzetközi kampányban igen nagy szerepet játszott. ${ }^{78}$ Ugyanakkor ez a kényszerszülte együttmüködés csak nagyon rövid „mézesheteket” hozott az anyaország és a diaszpóra kapcsolatában.

Ahogy a horvát diaszpóra egyik kiemelkedő szakértője, Winland írja, a kilencvenes években a diaszpóra és az anyaország egymás iránti „,vágyakozása” (vagyis az évtizedes egymástól való elszakadás utáni újbóli kapcsolódás) mellett egyaránt megtalálható volt az egymás „megvetése” is a kilencvenes években. ${ }^{79}$ Az ellentétek több okra vezethetőek vissza. Egyrészről az anyaország ellenérzéssel viseltetett a diaszpóra iránt amiatt, hogy a diaszpórában a horvát nemzeti identitás „közönséges”, meghaladott formában él, és ezzel összefüggésben elavult politikai elképzeléseik vannak az anyaországról. Az anyaország számára a kilencvenes években úgy tünhetett, hogy a diaszpóra túlzott mértékben be akar avatkozni a belügyekbe, emellett pedig anyagi hasznot is teremtenek maguknak az újonnan függetlenedett ország befektetési lehetőségeinek vindikálásával - amiből aztán Horvátországnak nem is lesz akkora haszna. Ezzel szemben a diaszpóra nehezményezte, hogy az anyaország nem vonta be őket az általuk kívánatosnak gondolt mértékben az ország átalakításába, nem használta ki a diaszpóra tapasztalatait a demokratikus átmenetben. A diaszpóra emiatt mellőzöttnek és elutasítottnak érezte magát. De Tudjmannak az usztasa állam bủneit relativizáló magatartása is riasztotta a diaszpóra egy részét, mert féltek, hogy ez a nemzetközi közvéleményre negatív

77 Winland, Daphne N.: Contingent Selves: The Croatian Diaspora and the Politics of Desire. Revija Za Sociologiju XXIX, 1998. 1-2. 47-57.

78 Koska, Viktor: The Development of Kin-State Policies and the Croatian Citizenship Regime. Minority Studies 16, no. Special Issue: Trends and Directions of Kin-State Policies in Europe and Across the Globe, 2013. 214-230.

${ }^{79}$ Winland, 1998.

REGIO 26. évf. (2018) 3. szám 155-234. 
hatást fog gyakorolni, és végeredményben kedvezőtlen hatással lesz a független Horvátország esélyeire. ${ }^{80}$

A nem teljes mértékben harmonikus viszony ellenére tény, hogy a horvátországi háború felerősítette a diaszpóra nemzeti identifikációját, és mobilizálta is a közösséget, kiváltképpen Kanadában. A HDZ vezetője, Franjo Tudjman már 1990-ben meglátogatta a nagyobb diaszpóraközösségeket, és pénzt, illetve politikai támogatást szerzett a diaszpórától. Nem elhanyagolható az a tény sem, hogy Tudjman kormányában a második legerősebb ember, Gojko Šušak a kanadai diaszpórából települt haza. A HDZ kampányára csak Torontóban több mint egymillió dollárt gyüjtöttek, ezért a diaszpóra úgy érezte, hogy nélkülük nem lenne független Horvátország. A diaszpóra vezetői nagyon szoros kapcsolatban voltak a HDZ politikusaival a kilencvenes években, és éppen emiatt a diaszpórán belüli kritikus hangokat próbálták elnémítani, ami viszont tovább mélyítette a diaszpóra belső megosztottságát.

A fentiek ismeretében nem meglepö, hogy a független Horvátország alkotmányába bekerült a külföldön élő horvátok iránti felelősségvállalás. Az Alkotmány 10. cikke így szól: „A Horvát Köztársaság védi azon állampolgárainak jogait és érdekeit, akik külföldön élnek vagy tartózkodnak, és elősegíti a hazával való kapcsolattartást. A Horvát Köztársaság a horvát nemzet más államokban élő részeinek külön gondoskodást és védelmet biztosít." $\mathrm{Az}$ alkotmányos klauzulában tehát általában jelennek meg a külföldön élö horvátok, nincs különbségtétel a nemzeti kisebbségként a régióban élő és az emigráns közösségek között.

$\mathrm{Az}$ anyaországi felelősségvállalás bekerült az 1991-ben elfogadott állampolgársági törvénybe is. A törvény rendelkezése értelmében a külföldön élő horvátok, amennyiben horvát származásukat bizonyítani tudják, állampolgárságot kaphatnak, vagyis kedvezményesen honosodhatnak, és ez az emigráns személy leszármazottaira is érvényes, a harmadik generációig. A törvény ugyanígy a volt Jugoszlávia területén kívül élő horvát személyek számára is elérhetővé teszi az állampolgárságot, és az ő körükben jóval népszerübb is a horvát állampolgárság: 1991 és 2010 között több mint egy millió állampolgársági kérvény érkezett a

${ }^{80}$ Uo.

REGIO 26. évf. (2018) 3. szám 155-234. 
Belügyminisztériumhoz, többségükben bosznia-hercegovinai állampolgárságú személyektől. ${ }^{81}$

Horvátország nem csak lakóhely nélküli állampolgárságot, hanem a választójogot is lehetővé tette a külföldön élö horvátoknak, sőt, külön parlamenti képviseletet biztosít a diaszpóra szavazóinak. Az 1995-ös választási törvény hozott létre egy önálló választói körzetet a külföldön élö horvátoknak, amelyből 12 parlamenti képviselőt tudtak delegálni a törvényhozásba - ugyanannyit, amennyit az országon belüli 10 másik választókerület. ${ }^{82}$

A külön diaszpóra választói körzet a horvát belpolitika egyik fontos ideológiai vitapontja lett a jobb- és baloldali pártok között, de a választási törvény sok kritikát kapott nemzetközi szinten is. A diaszpóra (némiképp felül-)reprezentáltságának kritikája politikaelméleti szempontból is releváns, hiszen az állampolgársági és választójogi szabályozással kapcsolatos szakirodalom egyik nagy tábora, a hagyományos republikánus ideológia szerint szavazati jog csak azokat illeti meg, akik a politikai döntések következményeit közvetlenül viselik, vagyis az állam területén élö állampolgárokat. ${ }^{83}$ Ugyanakkor a horvát esetben a kritikák mögött első sorban nem ideológiai megfontolás állt, hanem az, hogy a külföldön élő horvátok egyértelmüen elkötelezettek voltak Tudjman pártja mellett, így a választókörzetükből kizárólag a HDZ képviselőjelöltjei kerültek be a parlamentbe. ${ }^{84}$ Nemzetközi nyomásra később módosították a törvényt, amelynek eredményeképpen a külföldi horvátok által delegált parlamenti képviseleti helyek igazodtak a választói részvételhez és az átlagosan egy mandátum megszerzéséhez szükséges szavazatszámhoz. A reform eredményeként a 2003-as választáson már csak 4 parlamenti képviselő jutott a diaszpórának. 2011-ben, a horvát alkotmánybíróság felszólítására, hogy kiegyenlítsék a választókerületek méreteit, ismét módosították a

${ }^{81}$ Koska, 2013.

821991 és 1995 között is szavazhattak a külföldön élő állampolgárok, de ekkor még nem volt önálló választási körzetük, hanem csak pártlistára szavazhattak.

83 Bauböck, Rainer: Expansive Citizenship: Voting beyond Territory and Membership," PS: Political Science and Politics, 38, 2005. 4. 683-687.

84 Voting from Abroad: The International IDEA Handbook, 2007, http://www.idea.int/publications/voting_from_abroad/index.cfm.

REGIO 26. évf. (2018) 3. szám 155-234. 
választási törvényt - ekkortól pedig már csak 3 képviselőt választhatnak a külföldön élő horvát állampolgárok. ${ }^{85}$

Fontos adalék a horvát diaszpóra választójogához, hogy noha a külön diaszpóra-választókörzet indoklása az volt, hogy ezzel kárpótolják a diaszpórát a múltban ért sérelmekért, valamint kifejezzék hálájukat a horvát függetlenség elérésében nyújtott segítségükért, valójában a diaszpóra választói aktivitásának vizsgálói egyértelműen megállapították, hogy nem a kommunizmus elöl menekülő emigránsok azok, akik valóban aktívak a horvát parlamenti választásokon, hanem a bosznia-hercegovinai horvátok. ${ }^{86}$ A kétezres évek elején, a jobboldali kormányok fokozatos kiszorulásával párhuzamosan a diaszpóra meglehetősen háttérbe szorult, és csak 2011-ben került ismételten a horvát politika fókuszába.

A horvát diaszpórapolitika törvényi keretéhez az alkotmányos klauzulán és az állampolgársági és választójogi törvényen kívül hozzátartozik a 2011-ben elfogadott törvény a külföldön élő horvátokról. A törvény három kategóriát határoz meg a külföldön élő horvátokon belül: a határon túli (nemzeti kisebbségként elismert) horvátokat, a bosznia-hercegovinai horvátokat (akik ott államalkotó nemzet) és a diaszpórában élő horvátokat és azok leszármazottait. A törvény bevezeti a horvát állampolgársággal nem rendelkező külföldi horvát kategóriát is. Emiatt tehát a törvény státustörvényként is értelmezhető, hiszen az állampolgársággal nem rendelkező külföldi horvátok számára kedvezményekre jogosító státuszt hoz létre. ${ }^{87}$

A törvény együttmüködést, támogatást, valamint az esetleges hazatelepülésben való segítségnyújtást határozza meg célként. Előirányozza új intézményi struktúrák létrehozását, amelyek a külföldön élő horvátokkal való kapcsolattartásért és politikáért felelősek: egy hivatalt, egy kormánytanácsot és parlamenti bizottságot. A törvény ezen kívül felsorol több minisztériumot és intézményt, amely a külföldi horvátok számára biztosított támogatások koordinálásában részt vesz. A Külföldön Élő Horvátok

85 A diaszpóra és határon túli horvátok választói preferenciája továbbra is változatlan, a 2016-os parlamenti választásokon 62,72\%-uk a HDZ-re voksolt.

${ }^{86}$ Koska, 2013.

${ }^{87}$ A törvény úgy fogalmaz, hogy azok a horvátok tartoznak ebbe a kategóriába, akik olyan országokban élnek, amelyek nem engedélyezik a kettős állampolgárságot, és emiatt horvát állampolgárságukról le kellett mondaniuk.

REGIO 26. évf. (2018) 3. szám 155-234. 
Hivatalát 2012-ben hozták létre, azóta ez az intézmény felelös a diaszpórapolitikai támogatásokért és a kapcsolattartásért. $^{88} \mathrm{~A}$ támogatási programokról a Hivatal honlapjáról nem derül ki konkrét információ, pusztán elvi szinten említődik a diaszpóra kapcsán az identitásápolás fontossága, a kulturális és az oktatási támogatások. Szintén 2011-ben fogadtak el egy stratégiai dokumentumot, „Stratégia a Horvát Köztársaság és a Horvát Köztársaságon kívül élő horvátok kapcsolatáról” címmel. 2013-tól létezik a Külföldön Élő Horvátok Tanácsadó Testülete, amely mind a határon túli, mind a diaszpórában élő horvátok képviselőit egyesíti, és a horvát kormány mellett müködik.

A horvát diaszpórapolitikáról a következő állítások fogalmazhatóak meg. Az ország függetlenné válásakor a horvát nacionalista HDZ-vel a diaszpóra vezető köreiben igen szoros kapcsolat és együttmüködés alakult ki, és a diaszpóra együttesen sok szempontból erőteljesen kivette a részét a függetlenség elnyeréséért folytatott harcokból és az önálló Horvátország konszolidálásából. Az anyaország rögtön a kilencvenes években szimbolikus (alkotmány) és praktikus (állampolgárság) tettekkel igyekezett bebiztosítani a jó viszonyt és együttmüködést, a közvetlen egzisztenciális veszély elmúltával (és Franjo Tudjman halálával) azonban az egymás iránti figyelem kölcsönösen lankadt, és a horvát nemzetpolitika látványosabb célcsoportjává a boszniai horvátok léptek elő. 2011 után észrevehetô egy újabb odafordulás a diaszpóra felé, azonban ennek egyelöre csak a szándéknyilatkozat szintü körvonalai látszódnak. ${ }^{89}$

${ }^{88}$ A kilencvenes években rövid ideig saját minisztériuma is volt a diaszpórának, Emigrációs (1991), majd Hazatelepülési és Bevándorlási (1997) Minisztérium néven.

${ }^{89}$ A horvát diaszpóra egyik lapja szerint pedig pusztán a bennük rejlő választói potenciál kihasználásáról szól a felélesztett diaszpórapolitika. L.: Croatia: Still Playing Same Broken Record To Diaspora.

http://www.croexpress.eu/vijest.php?vijest=5533.

(Utolsó letöltés: 2017. május 16.)

REGIO 26. évf. (2018) 3. szám 155-234. 
Szerbia

Szerbia a horvátországihoz nagyon hasonló helyzetben van a külföldön élö szerbekkel kapcsolatosan. Egyrészt élnek szerbek a szomszédos országokban (Magyarország, Románia) nemzeti kisebbségekként, egy másik csoportot képeznek a volt Jugoszlávia államaiban élő szerbek, végül a harmadik csoportot pedig az emigrációs hullámok által létrejött szerb diaszpóra alkotja. Utóbbi nagyságrendjét a szerb külügyminisztérium 3,5 millióra becsüli, amelyből megközelítőleg 1,5 millió szerbnek van szerb állampolgársága is, ${ }^{90}$ de ebbe a másod- és harmadgenerációs szerb diaszpórát is bele kell érteni. A szerb diaszpóra fejlődéstörténete gyakorlatilag megegyezik a horvátéval: az első hullám a 19. század végi gazdasági emigráció volt, ezt követte a II. világháború alatti és utáni politikai indíttatású migráció, majd a hatvanas évektől egy enyhe, de folytonos, kisebb mértékben politikai, nagyobb részben gazdasági migráció. A kilencvenes évek szerb háborúi rengeteg szerbet kényszerítettek menekülésre, köztük igen sok magasan képzett szerb hagyta el az országot. Mivel a háborúk gazdaságra és az ország általános állapotára gyakorolt hatásai máig érzékelhetőek, az országból történő migráció aránya az egyik legmagasabb a keleteurópai térségben. ${ }^{91}$

A tengerentúli horvát diaszpóra háború alatti tevékenységével ellentétben az amerikai szerbek lobbija nem nevezhető sikeresnek. Egyedül az Egyesült-Királyságban élő szerbek érdekérvényesítő törekvése nevezhető bizonyos mértékben hatékonynak a kilencvenes években. ${ }^{92}$ A szerb állam és a diaszpóra közötti kapcsolatok sem voltak olyan szorosak a kilencvenes években, mint azt Horvátország esetében láttuk.

\footnotetext{
${ }^{90}$ Diaspora - General Information, MFA Serbia, http://www.mfa.gov.rs/en/consular-affairs/diaspora/diaspora-generalinformation. (Utolsó letöltés: 2017. május 17.)

${ }^{91}$ Migration in Serbia: A Country Profile, Migration in the Black Sea Region: Regional Overview, Country Profiles and Policy Recommendations (International Organization for Migration, 2008),

www.iom.hu/PDF/migration_profiles2008/Serbia_Profile2008.pdf.

${ }^{92}$ Hodge, Carole: The Serb Lobby in the United Kingdom. Donald W. Treadgold Papers no. 22. 1995.
}

REGIO 26. évf. (2018) 3. szám 155-234. 
Mivel a balkáni háborúk Szerbiában lényegében a kilencvenes években végig tartottak, Szerbia nagyjából tíz év késéssel kezdett el effektíve foglalkozni a külföldön élő szerbekkel. Az ország új alkotmányába is bekerült a külföldön élő szerbekért való felelősségvállalás. A szerb alkotmány 13. szakasza így szól: „A Szerb Köztársaság védelmezi állampolgárainak jogait és érdekeit külföldön. A Szerb Köztársaság fejleszti és előmozdítja a külföldön élő szerbek kapcsolatait az anyaországgal." Látható, hogy az alkotmányos felelősségvállalásban a külföldön élő szerbek egyes csoportjai között semmilyen különbségtétel nem jelenik meg.

Az alkotmányon kívül a jogi keretbe tartozik a diaszpóráról és a régióban élő szerbekről szóló törvény, amelyet 2009-ben fogadott el a szerb parlament. A törvény címéböl is látszik, hogy itt már megtörtént a különbségtétel a külföldön élő szerbek csoportjai között. A törvény értelmében a diaszpóra kategóriába a frissen emigrált szerb állampolgárok, valamint a korábban kivándoroltak és azok leszármazottai is beletartoznak. A „szerbek a régióban” kategóriába a volt jugoszláv államok, Magyarország, Albánia, Bulgária, Románia szerb közösségei tartoznak. A fogalmi distinkción kívül a törvény általánosságban meghatározza a Szerbia és a külföldi szerbek közötti kapcsolat prioritásait: nyelvoktatás, gazdasági együttmüködés, jogvédelem. Emellett a törvény létrehozza a régióbeli szerbek napját, továbbá a diaszpóra és régióbeli szerbek gyülését, amely az anyaország és a külföldön élő szerbek közötti konzultációs fórumként funkcionál. A gyülés munkájában a szerb tudományos, kulturális és vallási élet fontos aktorai is részt vesznek, ezen kívül a törvény rögzíti, hogy melyik közösségből hányan tagjai a gyülésnek. Emellett külön létezik egy-egy tanács a régióbeli szerbekkel való kapcsolattartásra, és külön tanács a diaszpórával való kommunikáció érdekében, amiben a miniszterek és az ortodox egyház képviselöje vesz részt. A törvény kimondja azt is, hogy a diaszpórának joga van megtanulni a cirill írást az anyaországban, amihez támogatást is biztosít az állam. Emellett rendelkezik arról, hogy milyen díjakat kaphatnak azok a külföldön élő szerbek, akik kiemelkedő módon segítik Szerbiát.

A szerb diaszpórapolitika intézményi kerete a szakpolitika rövid történelme ellenére rengeteget változott. Eleinte a Külügyminisztérium volt a diaszpórával való kapcsolattartásért a felelős, majd a diaszpóráról és a régióban élő szerbekről szóló törvény 
létrehozta a diaszpórával és a régióban élö szerbekkel való együttmüködés hivatalát. Egy rövid ideig létezett külön Vallás- és diaszpóraügyi minisztérium, de a 2017-es pillanatfelvétel szerint a Külügyminisztérium hatáskörébe tartozik a szakpolitika.

2011-ben készült el a szerb diaszpóra stratégia, az akkori Vallásés Diaszpóraügyi Minisztérium gondozásában. Ennek feladatait 2012-ben átvette a Diaszpóra Hivatal, majd 2014-ben a Külügyminisztérium. A stratégia az anyaország és a diaszpóra, valamint az anyaország és a régióbeli szerbek kapcsolatának megerősítését, illetve a diaszpóra nemzeti és kulturális identitásának megerősítését, érdek- és jogvédelmét, valamint a diaszpórában rejlö szakmai és anyagi erőforrások Szerbia gazdasági fejlesztésébe történő becsatornázását tüzi ki célul. A stratégia fö problémaként a magasan képzettek migrációját nevezi meg. Emellett listázza a régióban élő szerb közösségek fő problémáit és kihívásait is.

A 2004-es állampolgársági törvény lehetővé teszi a külföldön élő szerbek számára a szerb állampolgárság felvételét, mind az emigránsok és leszármazottaik, mind a régióban élő szerbek számára. A szerb származás bizonyítása rendkívül engedékeny, a törvény valójában semmilyen formai elöírással nem rendelkezik ennek módjáról, így meglehetösen rugalmas a törvény gyakorlatba ültetése. Ez azonban érdekes módon nem generált különösebb vitát a szerb politikában, és általánosan elmondható, hogy - mivel nem csak a szerb származásúak, hanem a Szerbia területén élö külföldiekkel és más etnikumúakkal szemben is könnyü feltételeket támaszt a törvény, - a belpolitikában egyetértés mutatkozik a törvény liberális szellemiségével kapcsolatban. ${ }^{93} \mathrm{Az}$ állampolgársággal együtt szavazati jog is jár, azzal a korlátozással, hogy a választójogukkal élni kívánóknak elözetesen regisztrálniuk kell, és a szavazat leadása csak személyesen van lehetőség a külföldön felállított szavazóhelyeken.

A szerb diaszpórapolitika több ponton is hasonlít a horvátra. A szerb esetben is jelen van a diaszpóra iránti állami felelősségvállalás alkotmányos és törvényi deklarálása, a

93 Rava, Nenad: Country Report: Serbia, EUDO Citizenship Observatory Country Reports, CITSEE (Badia Fiesolana, Italy: European University Institute, Revised and updated 2013), http://eudo-citizenship.eu/admin/?p=file\&appl=countryProfiles\&f=Serbia.pdf.

REGIO 26. évf. (2018) 3. szám 155-234. 
közigazgatás szintjén a szakpolitika saját intézményi kereten belül müködik. Az egyértelmüen látszódik, hogy - Horvátországgal ellentétben - Szerbiában a balkáni háborúk alatt nem „sajátította ki” a diaszpórát semmilyen politikai párt, így az anyaország és a diaszpóra kapcsolata egyrészt kevésbé „terhelt”, másrészt viszont nem is nevezhető túlságosan szorosnak. A diaszpórapolitika jobb strukturálását szolgáló stratégiai gondolkodás Szerbiában is megindult, ugyanakkor ennek eredményei nem látszódnak még.

\section{Lengyelország}

A lengyel diaszpóra megnevezése a lengyelül „Polonia”, ami a latin nyelvben Lengyelországra utal. A lengyel terminológia nem tesz tehát különbséget a kivándoroltak és a határmódosítás miatt külföldre került lengyel kisebbségek között, ök mindannyian Polonia részei. A lengyel külügyminisztérium szerint 15-20 millió a külföldön élő lengyelek száma. A diaszpóra kapcsán - a magyar esethez hasonlóan - különböző emigrációs hullámok eredményeként létrejött nagyon sokszínű csoportról beszélhetünk. Már Lengyelország felosztásakor megindult több kivándorló hullám, aztán a 19. század végi gazdasági kivándorlás alapozta meg a legnépesebb lengyel diaszpórát, az amerikait. A II. világháború alatt és után rengeteg politikai menekült, illetve a népes lengyel zsidóság nagy része hagyta el Lengyelországot. 1945 után a határmódosítások miatt is több lengyel közösség került a határon túlra, tehát a lengyel eset nem csak a diaszpóra szerkezete, hanem a határon túli kisebbségek helyzete miatt is hasonló a magyarhoz. Fontos megemlíteni, hogy a lengyel diaszpóra több mint 58\%-a Amerikában él, ahol majdnem 10 millió lengyelről lehet beszélni, de szintén milliós nagyságrendű a brazíliai, a franciaországi és a németországi diaszpóra is. A volt Szovjetunió országaiban (Ukrajna, Litvánia, Oroszország) többszázezres lengyel közösségek élnek. ${ }^{94}$

A kommunizmus évei alatt Lengyelország és a diaszpóra kapcsolata nem volt intenzív, hiszen a diaszpóra egy markáns része erőteljesen antikommunista volt. A rendszerváltás után ezért magától értetődő volt, hogy az új Lengyelország felveszi a kapcsolatot az

94 Halász Iván: A külhoni lengyelek és Lengyelország „diaszpóra politikája. Regio, 2003/4. 120-141.

REGIO 26. évf. (2018) 3. szám 155-234. 
elhanyagolt külföldön élö lengyelekkel. Ekkor még nem volt külön kormányzati egység a diaszpórával való kapcsolattartásra, így a Szenátuson és különböző alapítványokon keresztül történt a kapcsolat kiépítése és megerősítése, de az egyes minisztériumok (külügy, belügy, kulturális) illetékes föosztályai is foglalkoztak a kérdéssel. Lengyelország beindította TV Polonia néven a világ számos országában fogható, a külföldi lengyeleknek szóló tévécsatornát is. Eközben a diaszpóra aktív önszerveződésbe kezdett, és 1992-ben és 2001-ben a Polonia és a külföldön élő lengyelek kongresszusát megszervezve tett kísérletet arra, hogy egy diaszpóra csúcsszervezetet alapítsanak, amely az egész külföldön élö lengyelség képviselöje lehetne. ${ }^{95} \mathrm{~A}$ tény, hogy az amerikai lengyelek az anyaország NATO-csatlakozásakor komoly lobbitevékenységet végeztek, mutatja, hogy a kilencvenes években sikerült partneri viszonyt kialakítania az anyaországnak a diaszpórával.

A lengyel alkotmány 6.2. pontja szól a külföldön élő lengyelekkel kapcsolatos felelösségröl: „A Lengyel Köztársaság segítséget nyújt a külföldön élő lengyelek számára nemzeti-kulturális örökségükkel való kapcsolatuk fenntartásában." Nincs tehát utalás az alkotmányban arra, hogy a külföldön élö lengyeleknek bármilyen alcsoportjai lennének, amelyek esetleg differenciált támogatási politikát tételeznének fel, a gyakorlat azonban mégis azt mutatja, hogy jelentősen elválik a diaszpóra és a határon túlra került lengyelekkel kapcsolatos anyaországi politika. Utóbbinak két fö eleme van: ezen közösségek kulturális és szociális támogatása, illetve a kedvezötlen életkörülmények között, a volt Szovjetunió területén élők hazatelepítése (repatriálása). A nyugati diaszpóra számára nem kifejezetten az anyagi jellegü támogatások a jellemzőek, sokkal inkább a gyakorlati segítségnyújtás az oktatási és kulturális kérdésekben. ${ }^{96}$

$\mathrm{Az}$ első koherens politikai állásfoglalás a lengyel diaszpórapolitika céljairól 2002-ben született meg egy szenátusi határozat formájában. A határozat a külföldön élő lengyelekkel való kapcsolat prioritásairól szól, és noha a szöveg megkülönböztette a különbözö típusú külföldi lengyel közösségeket, a célokat tekintve egységes csoportként kezeli őket. A célkitüzések között a lengyel

${ }^{95}$ Uo.

${ }^{96}$ Uo.

REGIO 26. évf. (2018) 3. szám 155-234. 
kisebbségek jogvédelme, a nyelvtudás fejlesztése, a kultúra ápolása szerepel, valamint megfogalmazza azt az elvárást, hogy a külföldön élő lengyelek mozdítsák elő Lengyelország nemzeti érdekeit a lakóhelyük szerinti országban. ${ }^{97}$ Szintén 2002-ben vezették be a lengyel diaszpóra és a külföldi lengyelek emléknapját, amellyel az anyaország „elismerését fejezi ki a külföldön élő lengyeleknek az ország függetlenségének visszaszerzésében nyújtott eredményeikért, hüségükért és ragaszkodásukért, és az anyaországnak a legnehezebb pillanatokban nyújtott segítségükért"98.

Ugyanebben az időszakban már zajlott a lengyel státustörvény vitája, amelyet azonban csak 2007-ben fogadtak el. A Karta Polaka, azaz a lengyel kártya a magyar státustörvény által bevezetett magyarigazolványhoz rendkívül hasonló kedvezményeket biztosít a kártyát (azaz a lengyeligazolványt) kiváltó lengyel nemzetiségü személyeknek. A törvény hosszas vitákat követően végül csak a volt szovjet tagköztársaságok területén élő lengyelek számára tette lehetővé a kártya megszerzését, vagyis a magyar törvényhez hasonlóan területi korlátozással él, ezáltal pedig egyértelmüen elkülöníti a határon túli lengyeleket a diaszpórában élőktől.

A diaszpórapolitika törvényi keretéhez tartozik még az állampolgársági és választójogi szabályozás. Lengyelország lehetővé teszi az állampolgárság megszerzését a külföldön élő lengyelek számára, azzal a megkötéssel, hogy csak az 1918-as függetlenség után születettek leszármazottaira alkalmazható, és fontos kitétel az is, hogy az állampolgárság nem szakadhat meg a családon belül. Az 1990-es években a legtöbb állampolgársági kérvényt a klasszikus lengyel diaszpóraközösségekből, az USA-ból, Kanadából és NyugatEurópából adták be. ${ }^{99} \mathrm{~A}$ lengyel választási törvény lehetővé teszi a lengyelországi lakhellyel nem rendelkező állampolgárok számára is a választási részvételt parlamenti választásokon, ennek előfeltétele a választói névjegyzékbe történő regisztráció. A választójoggal személyesen, a konzuli szolgálatokon lehet élni, 2014-től a

${ }^{97}$ Uo.

${ }^{98}$ Day of the Polish diaspora and Poles abroad,

http://www.rzym.msz.gov.pl/en/news/day_of_the_polish_diaspora_and_poles_ab road. (Utolsó letöltés: 2017. május 18.)

99 Górny, Agata - Pudzianowska, Dorota: Country Report: Poland, EUDO Citizenship Observatory Country Reports. Badia Fiesolana, Italy: European University Institute, Revised and updated 2013.

REGIO 26. évf. (2018) 3. szám 155-234. 
levélszavazás is megengedett. A külföldön élö állampolgárok nem rendelkeznek külön képviselettel, szavazataikat a varsói központi választókerület szavazataihoz adják. ${ }^{100}$

Az Európai Unióhoz való csatlakozás Lengyelország esetében is a gazdasági- és/vagy munkamigráció egy új, meglehetősen intenzív szakaszát jelenti. A lengyelországi munkavállalók többsége NagyBritanniába és Németországba áramolt. Az Egyesült Királyságban a 2015-ös statisztikák szerint már a lengyelek adták a legtöbb külföldön született lakost, megelőzve a hagyományosan az első helyen szereplő Indiát. ${ }^{101} \mathrm{Az}$ új migrációs hullám eredményeként létrejövő új diaszpóraközösségek kihívás elé állították a lengyel diaszpórapolitikát, hiszen az 1990-től kialakult kapcsolatokon és struktúrákon keresztül ezek a személyek és közösségek már nem voltak elérhetőek.

Ebböl a megfontolásból 2011 után kezdődött meg egy tervezési folyamat Lengyelországban, amelynek célja az volt, hogy a legújabb kivándorló lengyeleket is becsatornázzák a diaszpórapolitikába. 2013-ban egy felmérés is készült a külföldi lengyelek Lengyelország irányába tanúsított attitüdjeiről. A felmérés eredménye azt mutatta, hogy a fiatal, frissen emigrált lengyelek csak mérsékelten érdeklődnek Lengyelország irántuk indított programjai iránt, és inkább szeretnének minél előbb beilleszkedni a befogadó ország társadalmába. A lengyelországi választásokon a megkérdezettek fele egyáltalán nem vesz részt, és csak $23 \%$-uk mondta azt, hogy rendszeresen leadja szavazatát. Társasági életük nem túl aktív, és nem érdeklödnek a helyi lengyel közösség élete vagy annak megszervezése iránt sem; a megkérdezettek csupán $12 \%$-a vesz részt valamilyen lengyel közösségi életben. Érdekes eredménye ugyanakkor a kutatásnak, hogy noha a lengyel emigránsok szervezett formában nem szívesen müködnek együtt a lengyelországi szervezetekkel a lakóhelyükön, de informális úton, illetve a

${ }^{100}$ Korzec, Piotr - Pudzianowska, Dorota: Access to Electoral Rights Poland, EUDO Citizenship Observatory Country Reports. Badia Fiesolana, Italy: European University Institute, Revised and updated 2013.

${ }^{101}$ Poland overtakes India as country of origin, UK Migration statistics show. BBC News, August 25, 2016, UK Politics, http://www.bbc.com/news/uk-politics37183733. (Utolsó letöltés: 2017. május 18.)

REGIO 26. évf. (2018) 3. szám 155-234. 
személyes életükben sokat tesznek Lengyelország ,promótálásáért” a lakóhelyük szerinti országban. ${ }^{102}$

A diaszpórapolitika intézményi kerete többrétü. Az emigrációs ügyekkel hagyományosan aktívan foglalkozó Szenátus mellett a Külügyminisztériumon belül is müködik a lengyel diaszpórával és a külföldi lengyelekkel való együttmüködés főosztálya, illetve a politikai mező mellett különböző alapítványok látják el a diaszpórával való kapcsolattartási és támogatási funkciókat. Az intézményesített egyeztetés Lengyelország és a diaszpóra között a Szenátuson belül egy tanácsadó testület formájában müködik, melybe a diaszpóra is delegálja képviselőit.

Lengyelország rögtön a kilencvenes évek elején szoros kapcsolat kialakítására törekedett a diaszpórában élö lengyelekkel, akik az anyaország közeledését pozitívan fogadták, az amerikai lengyelek sikeresnek mondható lobbitevékenységet is végeztek Lengyelország aktuális érdekeiért. A diaszpórapolitika a közigazgatási struktúrában (Szenátus, Külügyminisztérium) is hamar helyet kapott, és ezek a felelősségi területek 1990 óta kisebb változásokkal állandónak mondhatók. A diaszpóra és a határon túli lengyelek bizonyos jogi szövegekben azonos kategóriaként szerepelnek, máshol külön-külön kerülnek említésre, ám a szakpolitikai prioritások jelentősen eltérnek a két külföldi lengyel közösség esetében. Az állampolgárság és választói jog tekintetében nincs különbség a diaszpóra és a határon túli lengyelek között, a lengyel kártya viszont csak az utóbbi csoport számára elérhető. Az anyagi jellegü támogatások egyértelmủen a határon túli lengyelek támogatáspolitikáját jellemzik, a diaszpóra irányába hangsúlyosabbak a szimbolikus gesztusok, illetve az identitáserősítést célzó projektek. Az uniós csatlakozást követő legújabb migráció új helyzetet teremtett a lengyel diaszpórapolitika számára, és egyelöre úgy tűnik, hogy az ország az új kihívásokra adandó válasz keresésének fázisában jár.

102 Fiń, Anna et al.:Views and Attitudes of the Polish Community and Poles Living Abroad on the Policy Towards Polish Expatriate Communities. Poznań: Institute for Western Affairs, 2013.

REGIO 26. évf. (2018) 3. szám 155-234. 
Románia

Románia esetében az eddigi példákhoz hasonlóan beszélhetünk egy klasszikus diaszpóracsoportról, illetve a régióban élő román kisebbségekröl. Utóbbiak, akiket nevezhetünk határon túli románoknak, nagyon eltérő jellegü közösségek (egyes közösségek esetében vitatott is, hogy román etnikumúnak tekinthetőek-e, ilyenek például a szerbiai vlachok), és Romániához való kötődésük is változó. A román közvélemény és politika számára a moldovai románok a legfontosabbak, ugyanakkor más külhoni román közösségekről, például a szerbiai vlachokról, a horvátországi vagy görögországi románokról homályos, illetve gyakran romantikus elképzeléseik vannak az anyaországi románoknak. ${ }^{103}$ A diaszpóra fejlődéstörténete a klasszikus közép-európai mintázatot mutatja, bár azt hozzá kell tenni, hogy a kivándorlók száma Romániából a 20. század során jóval alulmúlta a legtöbb közép-európai ország adatait. ${ }^{104}$ Emiatt az 1989 előtt kivándorolt „klasszikus” diaszpóra nem volt annyira jelentős sem számarányát, sem szervezettségét tekintve, mint a horvát, a lengyel vagy a magyar.

A diaszpórával való anyaországi kapcsolat - eltérően a horvátországi és a lengyelországi esettől - sokáig a romániai forradalom után is fagyos volt. A forradalmat követően kb. 170000 román hagyta el az országot, akik, - mivel a kilencvenes évek politikai és gazdasági nehézségeiért az akkori elnököt hibáztatták, a kommunizmus alatt emigrált (illetve disszidált) románokkal abban a tekintetben egységet alkottak, hogy Ion Iliescu elnök iránt meglehetős ellenszenvvel viseltettek. (2004-ben egy kanadai látogatásakor ki is fütyülték és megdobálták Iliescut, mire ő válaszul durván sértegette az ellene tüntetőket. ${ }^{105}$ ) A kétezres években folytatódott az eröteljes kivándorlás, föleg a schengeni vízummentesség életbelépése, 2002 után. Becslések szerint 3-4 millió kivándorló él külföldön, főként a latin nyelvü nyugat-európai országokban.

\footnotetext{
103 Kántor Zoltán - Pászkán Zsolt: A határon túli románok és a románok státusztörvényei. Pro Minoritate, 2011 Tavasz, 70-81.

${ }^{104}$ Puskás, 1991.

${ }^{105}$ Kántor - Pászkán, 2011.
}

REGIO 26. évf. (2018) 3. szám 155-234. 
A román diaszpórapolitika törvényi keretének sarokköve a külföldön élő románokért való alkotmányos felelősségvállalás. A román alkotmány 7. szakasza így szól: „Az állam támogatja az ország határain kívüli románokkal való kapcsolattartást, és cselekszik az etnikai, kulturális, nyelvi és vallási identitásuk megőrzéséért, fejlesztéséért és kifejezéséért, tiszteletben tartva annak az államnak a törvényeit, amelynek az állampolgárai." Nincs tehát különbségtétel a határon túli és a diaszpórában élő románok között, célként pedig alapvetően az identitásőrzésben való anyaországi segítségnyújtás van megnevezve.

Románia 1991-es állampolgársági törvényével biztosította a külföldön élő románok számára a román állampolgárság felvételét. Az 1991-es törvény három módját nevezte meg az egyszerüsített állampolgárság szerzésnek: hazatelepülés, egyszerüsített honosítás (hazatelepülés nélkül), illetve restitúció, ami az 1989 előtt román állampolgárságuktól „többféle okból” vagy akaratuk ellenére megfosztott személyeknek szól (szintén hazatelepülés nélkül is). Utóbbi lehetőség a múlt igazságtalanságaiért való kárpótlásként értelmezendő, ugyanakkor ez a bekezdés az állampolgársági törvény egyik legvitatottabb pontja, emiatt számos módosításon át is esett. ${ }^{106}$ A kettős állampolgárságot megengedő törvény fő motivációja az volt, hogy a bukovinai és besszarábiai románok, akik 1940-ben a Szovjetunióhoz való csatoláskor elvesztették román állampolgárságukat, egyszerüsített úton válhassanak román állampolgárrá. Ez feszültséget generált Moldovával, és tömegével érkeztek állampolgársági kérelmek onnan. ${ }^{107}$

A külföldön élő román állampolgárok szavazati jogot is élveznek, kivéve az önkormányzati választásokat és a helyi népszavazásokat. A külföldön élö állampolgárok választójoga Románia esetében egy meglehetősen ellentmondásos és nagy vitákat kavaró törvény, főként

\footnotetext{
${ }^{106}$ Culic, Irina: From Restitution to Privileged Re-Naturalisation: The Expansive Politics of Dual Citizenship in Romania after 1989. Minority Studies, 16, 2013. 125-152. [Special Issue: Trends and Directions of Kin-State Policies in Europe and Across the Globe.]

107 Iordachi, Constantin: Citizenship and National Identity in Romania: A Historical Overview. Regio, 2002. 1. 3-34.
}

REGIO 26. évf. (2018) 3. szám 155-234. 
a 2009-es államfőválasztás óta. ${ }^{108}$ Ekkor ugyanis a választás eredménye pontosan a külföldön élő román állampolgárok szavazatain múlott, ugyanis a külföldi szavazatok összeszámolása fordította Traian Băsescu javára a szavazást. Băsescu 2004-től kezdődő elnöksége alatt a moldovai románok, illetve a Moldovával kapcsolatos külpolitikai tervek határozottan a román politika elöterébe kerültek, és ezzel párhuzamosan a külföldön élő románok szavazatainak maximálása is az elnök és pártjának „programpontjává” vált. ${ }^{109}$ Ez érthető módon az ellenzéki pártokat, pláne 2009 után, a külföldön élők szavazati jogának megkérdőjelezésére késztette, tehát nem mondható, hogy nemzeti konszenzus lenne a kettős állampolgárok szavazati jogáról Romániában. ${ }^{110}$

A határon túli kisebbségekkel bíró országok többségéhez hasonlóan Románia is elfogadott státustörvényt, az elsőt 1998-ban, majd egy újabb verziót 2007-ben. Az 1998-as státustörvény ,a világ bármely részén élő románoknak biztosított támogatásról” rendelkezik. Ahogy már a nevéböl is látszik, a törvény nem tartalmaz területi korlátozást, sem bármiféle distinkciót a különbözö külhoni román közösségeket illetően. A törvény egy támogatási alapot hozott létre, lényegében más rendelkezése nem volt. Nem adott ki igazolványt a külhoni románoknak, tehát nem tekinthető klasszikus státustörvénynek, és nem határozott meg kedvezményeket sem (kivéve egyet: a Romániában tanuló külhoni román diákok szállásának térítésmentes biztosítását).

$\mathrm{Az}$ újabb, 2007-es törvény a legújabb migrációs trendekre született válaszreakcióként, hiszen a kétezres években már érzékelhető volt, hogy egyre több román állampolgár vállal munkát Nyugat-Európában. A törvény neve némiképp módosult, „A más országokban élő románok támogatásáról" címet viseli. Ebben a törvényben külön figyelmet kap a legújabb diaszpóra. Az új státustörvény már különbséget tesz a határon túli románok két

${ }^{108}$ Dumbrava, Costica: Access to Electoral Rights Romania. EUDO Citizenship Observatory Country Reports. Badia Fiesolana, Italy: European University Institute, 2013.

${ }^{109}$ Kántor - Pászkán, 2011.

${ }^{110}$ A román pártrendszer ugyanakkor olyannyira nem nevezhető stabilnak, hogy nehéz örökérvényủ kategóriákat felállítani arról, hogy mely pártok támogatják és melyek nem a külföldön élő állampolgárok szavazati jogát.

REGIO 26. évf. (2018) 3. szám 155-234. 
csoportja között, és elkülöníti a Romániával szomszédos országokban, kisebbségben élőket a kivándorolt románoktól és azok leszármazottaitól. Ez a törvény is a romániai oktatást nevezi meg a külföldön élő románokat megillető jogok egyik legfontosabbjaként, ezen kívül a kultúra területén biztosít kedvezményeket. A törvény újdonsága, hogy felszólítja a román hatóságokat, hogy a külföldön dolgozó románok jogait monitorizálja, és jogsértés esetén lépjen fel az érdekükben.

Ami a román diaszpórapolitika intézményi kereteit illeti, alapvetően a külügyminisztérium, illetve azon belül a külhoni románokkal való kapcsolattartásért felelös föosztály felelős a szakterületért. Bizonyos időszakokban miniszteri megbízottat is kijelölnek a felelősségi terület élére, de összességében az állapítható meg, hogy nagyon diverz a román diaszpórapolitika intézményi és támogatási struktúrája. ${ }^{11}$ Alapvetően két nagyobb ágra oszthatóak a határon túli románokkal foglalkozó intézmények: Moldovával, illetve a határon túli románokkal foglalkozóakra. A diaszpóra az utóbbi keretében kap helyet. Alapvetően a programszerü támogatások, illetve az oktatás területén az alanyi jogon járó támogatások a hangsúlyosak, de hangsúlyozandó, hogy a Moldovának juttatott támogatások magasan dominálnak a többi határon túli román csoportnak juttatott támogatások felett. ${ }^{12} \mathrm{~A}$ közigazgatási egység mellett 2001-ben létrehozták a Világszerte Élö Románok Támogatásáért Minisztériumközi Bizottságot, amely a kormány tanácsadó testületeként müködik.

2013-ban fogadták el a „Világszerte élő románokkal való kapcsolattartásra irányuló stratégiát", amely a diaszpóra és a határon túli románokkal való kapcsolatokról és célokról egyaránt beszél. A stratégia a 2013 és 2016 közötti időszakra szólt. A dokumentum meglehetősen általános elveket (identitásőrzés, nyelvoktatás, hagyományőrzés, kapcsolattartás) sorakoztat fel, és a stratégiai célok megnevezésénél sem jut az általánosnál konkrétabb feladatok kijelöléséig. ${ }^{113}$ Jóval komolyabb a 2017-2020-as időszakra

${ }^{111}$ L. erről részletesen: Kiss Ágnes: Románia határon túli románságpolitikája az 1990-2004 között hatályos jogszabályok tükrében. Magyar Kisebbség, 2005. 12. 298-353.

112 Uo.

113 STRATEGIA PRIVIND RELAŢIA CU ROMÂNII DE PRETUTINDENI 2013-2016 (A világszerte élő románokkal való kapcsolattartásra irányuló

REGIO 26. évf. (2018) 3. szám 155-234. 
vonatkozó „Diaszpóra - Partner Románia fejlesztésében” címet viselő stratégiai dokumentum, amely a különbözö külhoni román közösségeket differenciáltabban kezeli, és a diaszpóra esetében azt hangsúlyozza, hogy hazautalásaival, szakmai tudásával hogyan segítheti az anyaország fejlődését. A stratégiai dokumentum konkrét akciótervvel és megvalósítási dátumokkal operál, melyek elsődlegesen a diaszpóra Románia gazdasági életbe történő bevonására, illetve a diaszpóra virtuális térben való összefogására irányulnak. ${ }^{114}$

A román diaszpórapolitika összegzéseként megállapítható, hogy a külföldön élő románok csoportjai közül az ország számára egyértelmüen a határon túli, azon belül is a moldovai románok képezik a legfontosabb célcsoportot, jóllehet a legtöbb dokumentumban a határon túli és a diaszpórában élő románok azonos kategóriában szerepelnek. A terminológia zavaros (a „világ bármely részén élő románok" elviekben a Románián belül élő románokat is jelentheti, hívja fel a figyelmet Kántor és Pászkán), nemzeti stratégiát pedig nehéz kiolvasni a román szabályozásokból. Ezek alapján juthatunk arra a konklúzióra, hogy a román diaszpórapolitika leginkább belpolitikai célokat szolgál. ${ }^{115}$ A legújabb elvándorlási hullám Romániát ugyan kifejezetten erőteljesen érinti, és noha ennek felismerése megtörtént, egyelöre elsősorban deklaratív szinten fogalmazódtak meg az erre adandó válaszok. A 2020-ig szóló stratégiai dokumentum a diaszpóra anyaországi fejlesztésébe való bevonásáról ugyan ígéretesnek tünik, és egy-két projekt (például Diaspora Start-up, Competitive Romania) már elindult, ám ezek eredményeiről még nem rendelkezünk információval.

stratégia 2013-2016) (Ministerul Afacerilor Externe Departamentul Politici pentru Relaţia cu Românii de Pretutindeni, 2013), http://www.dprp.gov.ro/wpcontent/uploads/2014/03/Strategie-2013.pdf.

114 "Diaspora - Partener Pentru Dezvoltarea Romaniei (Diaszpóra - Partner Románia fejlesztésében)" (Ministerul Afacerilor Externe Departamentul Politici pentru Relaţia cu Românii de Pretutindeni, 2016), http://www.dprp.gov.ro/wpcontent/uploads/2016/11/viziune-29.11.2016-.pdf.

${ }^{115}$ Kántor - Pászkán, 2011. 


\section{Szlovákia}

A szlovák diaszpóra fejlődéstörténete a klasszikus közép-európai mintázatot követi, és a magyar diaszpórára abban az értelemben is nagyon hasonlít, hogy a legnépesebb szlovák diaszpóra az Egyesült Államokban él. Az emigráció által létrejött külföldi szlovák közösségek mellett Szlovákia esetében is beszélhetünk határon túli szlovákokról, akik a volt Osztrák-Magyar Monarchia területén szétszórt közösségekben élnek. Külön említést érdemel, hogy a csehszlovák állam története miatt a csehországi szlovákok egy olyan külhoni szlovák alcsoportot alkotnak, amelyek „külhonisága” igen rövid történetre tekint csak vissza. Az összes külföldi szlovák számát a szlovák hatóságok 1,5-2 millióra becsülik.

Mint eddig mindegyik tárgyalt ország esetében láttuk, Szlovákia is beillesztette alkotmányába a külföldön élö szlovákokért vállalt anyaországi felelősséget. Az Alkotmány 7(a) cikke így szól: „A Szlovák Köztársaság támogatja a külföldön élő szlovákok nemzeti öntudatát és kulturális identitását, továbbá pártolja az e cél elérésére létrehozott intézményeiket és az anyaországgal való kapcsolattartást.” A külföldön élő szlovákok különböző csoportjairól az Alkotmány tehát nem tesz említést.

A szlovák diaszpórapolitika törvényi keretéhez hozzátartozik az 1997-ben elfogadott, majd a magyar státustörvényre való reakcióként 2005-ben módosított szlovák státustörvény. A törvény alapján a szlovák felmenőkkel rendelkező személyek (3. generációig) kérvényezhetik a „külföldön élő szlovák státust”, és kapnak róla tanúsítványt is. A jogszabály tehát egyszerre státustörvény, kedvezménytörvény és honfitársi jogszabály, ${ }^{116}$ és fontos kitétele, hogy nem szükíti le az érintettek körét a határon túli szlovák kisebbségekre, hanem a diaszpórára is érvényes. A törvény által garantált kedvezmények között letelepedés, munkavállalás, tanulás, illetve utazási kedvezmények szerepelnek. Annak ellenére, hogy a törvény minden külföldön élö szlovákra érvényes és viszonylag bőkezü a biztosított kedvezményeket illetően, nagyon kevesen

\footnotetext{
${ }^{116}$ Halász Iván: Szlovákia, a külföldön élő szlovák állampolgárok és a határon túli szlovákok Kapcsolatai." In Állampolgárság Európában, 2005. Europa Institut Budapest, 2005.

http://www.europainstitut.hu/index.php/24-sonstiges/915-allampolgarsag-halasz.
}

REGIO 26. évf. (2018) 3. szám 155-234. 
(2005-ig csak tízezren) éltek a státustörvény adta lehetőséggel és váltották ki szlovák kártyájukat.

A korai státustörvény magyarázata az, hogy Szlovákia már a függetlenedéskor kedvezni kívánt a föleg észak-amerikai diaszpórának, bízva abban, hogy tőkét és politikai lobbit fognak biztosítani Szlovákiának. Ez azonban naiv elvárás volt, ugyanis az amerikai és kanadai szlovák diaszpóra, bár számszerüleg nem jelentéktelen, a más közép-európai (például a lengyel vagy magyar) diaszpóráknál nagyobb mértékben asszimilálódott, illetve megosztottabb is. ${ }^{117}$

Az állampolgársági szabályozás Szlovákia esetében nem vizsgálható a 2010 utáni magyarországi állampolgársági törvénymódosítás figyelembevétele nélkül. 2010-ig bezáróan Szlovákia lehetővé tette a kettős állampolgárságot, azonban fontos kitétel, hogy szlovákiai lakóhely nélkül nem volt lehetséges az ország állampolgárává válni. Szlovákiai lakóhely nélkül tehát nem válhatott senki szlovák állampolgárrá, de a többes állampolgárságot tolerálta a rendszer. Ugyanakkor kedvezményesen honosodhattak a korábbi csehszlovák állampolgárok, azok, akik a Csehszlovák államszövetség idején elvesztették csehszlovák állampolgárságukat, illetve azok, akik az 1997-es státustörvény értelmében szlovák kártyával rendelkeztek. Esetükben a törvény nem követelt meg az állampolgárság felvétele előtt 8 év szlovákiai tartózkodást (ami a nem szlovák származású kérelmezőkre viszont vonatkozott), csak 3 évnyi helyben lakást, illetve nem mentesültek a nyelvtudás bizonyításának követelménye alól sem. Nem volt tehát kifejezetten könnyü a szlovák származásúak honosodása 2010 elött sem.

A 2010-es szigorítás a magyar állampolgársági törvény módosítására volt válaszreakció. Mivel Magyarország lehetővé tette, hogy a külföldön élő magyarok magyarországi lakóhely nélkül is állampolgárokká váljanak, Szlovákia úgy módosította a törvényt, hogy azok a szlovák állampolgárok, akik valamely más ország állampolgárságát felveszik, elveszítik a szlovák állampolgárságukat. A szlovák állampolgárság elvesztésének kilátása elrettentő azoknak a szlovákiai magyaroknak, akik Magyarországra való áttelepülés nélkül szeretnék felvenni a magyar állampolgárságot, ugyanakkor a szlovák törvénymódosítás nem csak a magyar nemzetiségü szlovák

117 Uo.

REGIO 26. évf. (2018) 3. szám 155-234. 
állampolgárokat hozza nehéz helyzetbe, hanem például a cseh és szlovák kettős állampolgárokat is, valamint azokat a szlovákokat, akik szlovák állampolgárságukat megtartva külföldön élnek, és a lakóhelyük szerinti országban állampolgárságot szereztek. 2010 óta tehát Szlovákia tiltja a kettős állampolgárságot.

A szlovák diaszpórapolitika intézményi reprezentánsa a Külügyminisztérium, illetve a státustörvény 2005-ös módosításával ${ }^{118}$ létrehozták a Külföldön élő szlovákok hivatalát. A kormányzati struktúrák mellett már 1995-től létezik a House of Expatriate Slovaks, azaz a külföldön élő szlovákok háza, amelynek célja a kulturális együttmüködések koordinálása és a külföldi szlovák intézmények támogatása. ${ }^{119}$

A diaszpórával való kapcsolattartás és dialógus biztosítása a Magyar Állandó Értekezletre nagyon hasonlító keretben történik. 1999 óta létezik a Szlovák Köztársaság és Külföldi Szlovákok Állandó Értekezlete, amelyet évente rendeznek meg, azonban a szlovák állam részéről általában alacsonyabb szintü politikai szereplő szokott részt venni rajta (a magyar kormányok miniszterelnöki szinten is képviseltetik magukat, Szlovákia esetében többnyire államtitkári szintü részvétel van). A Szlovák Állandó Értekezleten 2002-ben a résztvevők létrehozták a Külföldi Szlovákok Világszövetségét. Ez 23 ország 98 tagszervezetéböl áll. A szervezet célja a külföldön élő szlovákok érdekeinek koordinált képviselete. ${ }^{120}$ Szintén az Állandó Értekezlet kezdeményezte a külföldi szlovákok múzeumának létrehozását 2016-ban. ${ }^{121}$

A szlovák diaszpórapolitikáról a következő megállapítások tehetőek. Az ország nagyszámú, és a közép-európai országokéhoz hasonló struktúrájú diaszpórával bír. Az ország függetlenedését követő években a szlovák politikai elit bízott abban, hogy - kivált az

\footnotetext{
118 A 2005-ös törvénymódosítás szintén egy magyar törvénykezésre, a magyar státustörvényre volt válaszreakció, de mivel a diaszpórapolitika szempontjából ez kevésbé releváns, ezért részleteiben ezt nem tárgyalom.

${ }^{119}$ Kusa, Dagmar: The Slovak Question and the Slovak Answer. In: Bauböck, Rainer - Perchinig, Bernhard - Sievers, Wiebke (eds.): Citizenship Policies in the New Europe. Amsterdam: University Press, 2009.

${ }^{120}$ Halász, 2005.

${ }^{121}$ Centre for Slovaks Abroad Founded in Bratislava, spectator.sme.sk, October 31, 2016, https://spectator.sme.sk/c/20372025/centre-for-slovaks-abroadfounded-in-bratislava.html. (Utolsó letöltés: 2017. május 21.
}

REGIO 26. évf. (2018) 3. szám 155-234. 
Észak-Amerikában élő szlovák diaszpóra - intenzíven bekapcsolódik majd az ország gazdasági fejlesztésébe, illetve lobbierőket fog mozgósítani a szlovák nemzeti érdekekért. Emiatt az első évtizedben az ország külföldön élő szlovákokat érintő politikájában a diaszpóra és a határon túli szlovákok kérdése nem vált szét, a biztosított kedvezmények és szimbolikus gesztusok egyformán érintették a két csoportot. A napnyugaton élő szlovákokhoz füzött remények azonban hamar szertefoszlottak, így a diaszpórapolitika is elvesztette kezdeti lendületét. A magyar státustörvény elfogadására, illetve a magyar állampolgársági törvény módosítására adott szlovák válaszreakciók arra engednek következtetni, hogy a szlovák diaszpórapolitika nagymértékben az ország szomszédsági és külpolitikájának függvénye, egyfajta reaktív szakpolitika, amelyben a külföldi szlovákok támogatása többnyire szimbolikus gesztusokban merül ki. Az országot a többi közép-európai államhoz hasonlóan intenzíven érintő legújabb migrációra még diskurzus szintjén sem keresi a választ a szlovák politikai elit. Ugyanakkor a külföldi szlovákok proaktív szereplőkké tudnak előlépni a szlovák diaszpórapolitika gyakran légüres terében, amelyre a szlovák állam partnerként reagál.

\section{Szlovénia}

Szlovénia diaszpórájának fejlődése szintén az Osztrák-Magyar Monarchia területéről való 19 . század végi kivándorlási hullámmal kezdődött meg, amit a világháborús menekültek egészítettek ki. Szlovénia helyzete ugyanakkor abból a szempontból egyedi az eddig tárgyalt országokhoz képest, hogy a jugoszláv időkben az ország inkább bevándorlási célpont volt, hiszen gazdasági mutatói felülmúlták a jugoszláv tagállamokét. Mivel a szlovéniai függetlenedés nem torkollt a többi ex-jugoszláv államéhoz hasonló háborúba, a kivándorlás 1990-et követően sem indult be. Szlovénia területéről nagyobb mértékủ kivándorlás 1945-öt követően ezért csak 2004 után kezdődött (ezres nagyságrendről beszélhetünk), aminek eredményeként ma az EU országaiban kb. $40 \quad 000$ szlovén 
állampolgár él. ${ }^{122} \mathrm{Az}$ elvándorlók többnyire a magasan képzettek köréből kerülnek ki. A diaszpóra mellett Szlovénia esetében is fontos tényező a határon túli szlovénok kérdése; a legfontosabb ilyen szlovén közösségek Olaszországban és Ausztriában élnek, de a többi, Szlovéniával szomszédos országban is vannak kisebb (és kevésbé szervezett, illetve erősebben asszimilálódott) szlovén kisebbségek.

Szlovénia alkotmányának 5. cikke szól a külföldön élő szlovénokért vállalt anyaországi felelősségről: „Az állam saját területén védi az ember jogait és alapvető szabadságjogait, biztosítja az őshonos olasz és magyar nemzeti közösség jogait. Gondoskodik az őshonos szlovén nemzeti kisebbségekröl a szomszédos országokban, a kivándorolt szlovénekről és a vendégmunkásokról, valamint elősegíti kapcsolataikat hazájukkal. (...) Azok a szlovének, akik nem szlovén állampolgárok, Szlovéniában külön jogokat és kedvezményeket élvezhetnek. E jogok és kedvezmények fajtáit és kereteit törvény állapítja meg."

A külföldön élő szlovének jogairól tehát az Alkotmány értelmében külön törvénynek kell rendelkeznie, ez azonban csak 2006-ban született meg. Noha 1996-ban már egy határozat elfogadásra került a témában, az azonban csak a szomszédos országokban élő őshonos szlovén kisebbségek helyzetéről rendelkezett. Ezt követte egy 2002-es állásfoglalás a külföldön élő szlovénekröl. ${ }^{123}$ A 2006-os törvény a külföldön élő szlovének és Szlovénia kapcsolatáról szól, és leszögezi, hogy minden szlovén, lakóhelyétől függetlenül része a szlovén nemzetnek, amelynek Szlovénia az anyaállama. A törvény szlovén státustörvényként is funkcionál, hiszen bevezeti az ,állampolgárság nélküli külföldi szlovén" státusát. Az állampolgársággal nem bíró külföldi szlovének a törvény értelmében kérvényezhetik a külföldi szlovén státust, ennek feltétele a szlovén származás (ennek bizonyítása nincs

${ }^{122}$ Badurashvili, Irina: Diaspora and Government: Cases of Ireland, Italy and Slovenia. In Promoting Well Managed Migration between The EU and Georgia. Tbilisi: Caucasus Institute for Peace, Democracy and Development, 2014.

${ }^{123}$ Medved, Felicita: 'Unified Slovenian Nation': Slovenian Citizenship Policy towards Slovenians Abroad. Minority Studies, 16., 2013. 153-187. [Special Issue: Trends and Directions of Kin-State Policies in Europe and Across the Globe]

REGIO 26. évf. (2018) 3. szám 155-234. 
specifikálva ${ }^{124}$ ), aktív részvétel valamilyen külföldi szlovén szervezetben, és effektív kapcsolat az anyaországgal. A külföldi szlovén státusát bárhol élő szlovén kérvényezheti, a törvény nem szab területi korlátozást. A státussal kedvezmények járnak a munkavállalás, oktatás, kultúra és kutatás terén Szlovénia területén belül.

A 2006-os törvény ezen kívül a hazatelepülést is szabályozza. Ez a lehetőség olyan szlovén személyekre érvényes, akik gazdaságilag nehéz helyzetü országban élnek. Ebben az esetben Szlovénia állja a hazatelepülés költségeit, illetve bizonyos támogatásokat is ad az anyaországi integrációhoz. Ez a támogatási forma nem nevezhetö kifejezetten eredményesnek, ugyanis mindössze pár argentínai szlovén család élt a lehetőséggel a kétezres évek elején.

Az állampolgársági szabályozás Szlovénia esetében kifejezetten érdekes, ugyanis létezik is, meg nem is a külföldön élö, Szlovéniában állandó lakóhellyel nem rendelkező szlovének számára kedvezményes honosítás. Az állampolgársági törvény alapvetően azt mondja ki, hogy a külföldön élő szlovének vagy szlovén származású személyek (negyedik generációig) kedvezményesen kaphatják meg a szlovén állampolgárságot, amennyiben Szlovéniában telepednek le. Ugyanakkor a törvény lehetővé teszi az úgynevezett „,kivételes egyszerüsített honosítást”, amely értelmében szlovén állampolgárság adható egyszerüsített eljárásban olyan személyeknek, akik szlovén állampolgársággal való felruházása szlovén nemzeti érdeket szolgál, és amennyiben az adott személy szlovén származású, úgy esetében a szlovéniai lakhely kritériumának nem kell megfelelni. A gyakorlatban a szlovén származású személyek állampolgárság igénylésekor elegendő ok szokott lenni a szlovén származás ahhoz, hogy esetükben a „nemzeti érdekeket szolgáló” érvre hivatkozzanak, s mivel esetükben a szlovéniai lakóhelytől el lehet tekinteni, így ha törvényi szinten nem is explicit, a gyakorlatban mégis müködik a külföldi szlovének lakóhely nélküli állampolgárság-szerzése. ${ }^{125}$

A külföldön élő, szlovéniai lakóhellyel nem rendelkező állampolgárok szavazati joggal is rendelkeznek. Levélszavazásra,

\footnotetext{
124 Valentinčič, Dejan: Slovenia's Attitude Towards Slovenian Minorities in Neighbouring Countries. European Perspectives - Journal on European Perspectives of the Western Balkans 6, 2014. 2. 63-83.

${ }^{125}$ Medved, 2013.
}

REGIO 26. évf. (2018) 3. szám 155-234. 
illetve diplomáciai és konzuli képviseleteken személyes szavazásra van lehetőségük a parlamenti és elnökválasztások alkalmával. Szavazataikat ahhoz a választókerülethez számolják, ahol nekik vagy felmenőiknek a legutolsó lakóhelyük volt, ha ezt nem lehet megállapítani, akkor az állampolgár maga választhatja ki a választókerületet. ${ }^{126}$

A szlovén diaszpórapolitika intézményi felelöse a Külhoni és a Diaszpórában Élő Szlovének Kormányhivatala, amely önálló, egyik minisztérium alá sem rendelt kormányzati egység. A 2006-os státustörvény értelmében élén tárca nélküli miniszter áll, korábban államtitkári szintű vezetője volt. A Hivatal felelös a külföldi szlovén közösségekkel való kapcsolattartásért és együttmüködésért, illetve támogatásukért. ${ }^{127}$ A diaszpóra oldaláról 1991 óta létezik a Szlovén Világkongresszus, amely a külföldi szlovének fö ernyőszervezeteként jött létre, de tevékenysége elsősorban szakmai konferenciák szervezésében nyilvánul meg. ${ }^{128}$ A 2006-os státusörvény létrehozta a Külföldi Szlovének Tanácsát és a Szomszédos Országokban Élő Szlovének Tanácsát, mindkettőt a szlovén kormány és a külföldi szlovénekkel való egyeztetés céljából. Mindkét tanácsnak a miniszterelnök az elnöke, a tagok pedig a hazai kormányzati szférából és az érintett közösségekböl kerülnek ki. ${ }^{129}$

A kétezres évek elejétől beinduló új migrációs hullámra és annak kihívásaira Szlovénia - a többi közép-európai állammal szemben szinte az első perctől kezdve keresi a választ. Dokumentumok szintjén 2008-ban a külföldön élö szlovének és Szlovénia kapcsolatáról fogadtak el egy stratégiát, amelyet 2009-ben egy akcióterv követett a külföldön élő szlovén származású kutatókkal és szakértőkkel való együttmüködésről - vagyis a magasan képzettek elvándorlását valóban hamar felismerték és próbálták kezelni. Az akcióterv eredménye lett többek között az is, hogy a szlovén tudományos tanácsba is meghívták a külföldön élő szlovén kutatókat, ezáltal próbálva meg bevonni öket az anyaországi

126 Accetto, Matej: Access to Electoral Rights Slovenia. EUDO Citizenship Observatory Country Reports. Badia Fiesolana, Italy: European University Institute, 2013.

127 Areas of Activity|Government's Office for Slovenians Abroad, http://www.uszs.gov.si/en/areas_of_activity/. (Utolsó letöltés: 2017. május 24.)

${ }^{128}$ Badurashvili, 2015.

${ }^{129}$ Medved, 2013.

REGIO 26. évf. (2018) 3. szám 155-234. 
tudománypolitikába. 2010-ben egy másik akciótervet is elfogadtak, amely a szomszédos államokban és a külföldön élő szlovén fiatalok támogatásáról szól. ${ }^{130} \mathrm{Az}$ akcióterv célja a másod- és harmadgenerációs szlovén fiatalok identitáserösítése, amely nyelvtanulással és csereprogramok keretében valósulhat meg.

$\mathrm{Az}$ új emigrációra való reagálás nem csak szimbolikus gesztusokban és az anyaországi kapcsolatok megerősítésében testesül meg, hanem Szlovénia próbálkozik a külföldi tőkeerős szlovénokban rejlő gazdasági lehetőségek kihasználására is. Ennek példái a 2003-ban Slovene Business Network Initiative és a 2004ben Business Development Council for Slovenes from Abroad néven indult kezdeményezések, amelyek a diaszpórapolitika kifejezetten profitorientált projektjei. ${ }^{131}$

Szlovénia viszonylag kis diaszpórával rendelkezik, amelynek 1945 óta lényegében a kétezres évek elejéig nem volt jelentősebb utánpótlása. A diaszpórapolitika törvényi, intézményi és szimbolikus szinten is összefonódik a határon túli őshonos szlovén kisebbségekkel, a különböző külföldi közösségek között különbségtétel ezeken az elemzési szinteken nem látható. Ez alól egyedül a legújabb migráció kihívásainak kezelése, illetve az abban rejlő potenciál kihasználásának kezdeti lépései a kivételek, amelyek elsősorban nyilvánvalóan a legújabb diaszpóra csoportokat célozzák.

\section{Regionális következtetések}

A közép-európai diaszpóra fejlődéstörténetében a 20. század közepéig a kivándorlási hullámok hasonló jellemzőkkel bíró diaszpóraközösségeket eredményeztek minden vizsgált ország esetében, a „szétfejlődés” 1945 után következett be, amikor különböző célú és volumenű kivándorlási hullámok eredményeként különböző karakterü emigráns csoportok váltak a diaszpóra részévé. Az 1990 utáni időszak egy újabb nagy választóvonalat jelent, hiszen ekkor megint csak nagyon eltérő az egyes országok esetében, hogy mikor és milyen karakterü csoportok vándoroltak vagy menekültek el az országból.

\footnotetext{
${ }^{130}$ Legislation | Government's Office for Slovenians Abroad, http://www.uszs.gov.si/en/legislation/. (Utolsó letöltés: 2017. május 15.)

${ }^{131}$ Badurashvili, 2015.
}

REGIO 26. évf. (2018) 3. szám 155-234. 
Közös diaszpórapolitikai elemnek tekinthetjük azt, hogy 1945 és 1990 között az anyaországok nem, vagy csak alig tartottak fent kapcsolatot a diaszpórában élőkkel, illetve egyes időszakokban kifejezetten ellenséges volt a diaszpóra nemzeti és/vagy demokratikus csoportjainak az anyaországi kommunista vezetéshez való viszonya. Emiatt csak 1990 után beszélhetünk valódi diaszpórapolitikákról a tárgyalt országok esetében. További közös jellemzőnek tekinthetjük azt is, hogy a diaszpóra felé irányuló politika nagymértékben összefonódik az anyaország határon túli nemzeti kisebbségei felé irányuló politikákkal, mind szimbolikus, mind törvényi, mind intézményi értelemben. Az eltérések viszont jól megragadhatóak abban, hogy milyen mértékü összefonódásról beszélhetünk az egyes országok esetében a kétféle külföldön élö népességet célzó politikák területén.

Láthattuk, hogy mindegyik tárgyalt ország alkotmányában szerepel valamilyen formában a külföldön élő „nemzetrészek” iránti felelősségvállalás, abban viszont már különbségeket látunk, hogy külön említik-e a diaszpórát és a szomszédos államokban élő kisebbségeket, vagy osztatlan csoportként kerülnek említésre. Szintén minden ország esetében láttuk, hogy valamilyen törvény keretében kezeli a külföldön élők státusát. Ezek a legtöbb esetben szó szerint státustörvények, a szerb és a román törvényt kivéve, amelyek nem hoznak létre valódi külhoni ,státust”. A közép-európai státustörvények közül a szlovák, a szlovén és a horvát egyaránt vonatkozik a diaszpórában élőkre és a régióban élő határon túli közösségekre, míg a lengyel csak a posztszovjet térségben élő lengyel kisebbségekre vonatkozik.

$\mathrm{Az}$ állampolgársági szabályozásokat is vizsgáltam abból a szempontból, hogy lehetővé teszik-e az anyaország állampolgárságának felvételét anyaországi lakóhely megléte nélkül. Ez a kitétel azért fontos, mert a frissen kivándorolt csoportokat kivéve a diaszpórában élöknek csak ritkán van anyaországi lakóhelye. A vizsgált országok közül egyedül Szlovákia nem teszi lehetővé a kedvezményes honosításnak ezt a fajtáját, ám ismételten hangsúlyozni kell, hogy a szlovák szabályozást a magyar állampolgársági törvény reakciójaként kell értelmezni, és nem elsősorban a szlovák diaszpóra iránti viszonyulásként. Szlovénia esetében hivatalosan nincs mód a kedvezményes honosításra, ugyanakkor a törvénynek vannak olyan rendelkezései, amelyek

REGIO 26. évf. (2018) 3. szám 155-234. 
biztosítanak kiskaput a külföldön élő szlovének és a szlovén származásúak számára a lakóhely nélküli állampolgárság megszerzésére.

$\mathrm{Az}$ is megállapítható, hogy a külföldön élő állampolgárok számára szinte mindegyik országban biztosított a szavazati jog, itt az egyetlen kivétel Szlovákia, ahol eleve nincs mód kettős állampolgárságra. ${ }^{132} \mathrm{~A}$ külföldön élő állampolgárok szavazati joga a kilencvenes években Horvátország esetében politikai vitákat és feszültséget okozott, Romániában pedig bizonyos időszakokban döntő fontosságúnak bizonyult a diaszpóra szavazata, ezért érzékeny kérdésnek számít, a többi országban viszont nem generál különösebb problémát szavazati jogmegadása.

A diaszpórapolitika intézményi kerete egyes országokban stabil, máshol kifejezetten változó volt 1990 óta. Szlovákia, Szlovénia és Horvátország esetében jelenleg kormányhivatal felel a diaszpórával való kapcsolattartásért és támogatásokért, de utóbbiban sokáig külön minisztériuma volt a diaszpórának. Romániában korábban szintén létezett diaszpóraügyi minisztérium, jelenleg azonban a külügyminisztériumhoz tartozik a felelősségi terület. Csakúgy, mint Lengyelországban, ahol viszont a Szenátus hagyományosan igen aktív a diaszpórát érintő ügyekben, így ez a két testület osztozik a szakpolitika irányításán. Szerbiában jelenleg szintén saját minisztériuma van a diaszpórának. Az intézményi kerethez tartoznak a diaszpórával való dialógus biztosítását szolgáló fórumok is, amelyeket mindegyik országban megtalálunk valamilyen formában, Romániát kivéve.

A kétezres évektől - Szlovákiát kivéve - a vizsgált országokban láthatóak annak jelei, hogy a legújabb kivándorlási hullámra igyekeznek valamilyen választ adni az anyaországi kormányok. Jóllehet ezeket a dokumentumokat stratégiáknak nevezik ezek az országok, valójában stratégiai tervezés, arra épülő vagy építhető elemek csak elvétve találhatóak a dokumentumokban. Többnyire tehát arról van szó, hogy diszkurzív szinten megjelenik az új diaszpórával járó kihívásokra adandó válaszok igénye a kétezres-

132 Ez természetesen egy leegyszerüsítő állítás, hiszen azok a szlovák állampolgárok, akik külföldön élnek, de nem vették fel a másik ország állampolgárságát (vagyis nem kettős állampolgárok), természetesen élhetnek választójogukkal.

REGIO 26. évf. (2018) 3. szám 155-234. 
kétezertízes években, de valódi koncepciót egyelőre csak Szlovénia esetében látni (illetve a legutóbbi, 2017-es román stratégia mögött feltételezhetünk valós tervezési munkát, ám ennek valódiságáról és komolyságáról még nem lehet ítéletet mondani).

A papírforma szerinti jellemzők alapján tehát azt mondhatnánk, hogy a közép-európai országok diaszpórapolitikája nagyon hasonló, hiszen szinte mindegyik esetében ugyanazokat az elemeket fedezzük fel. Ennek ellenére mégis azt gondolom, hogy a lényeg a részletekben rejlik, nem a deskriptív adatolásban. Összehasonlításban, elemekre lebontva bármennyire hasonló például a horvát és a lengyel diaszpórapolitika, ha számításba vesszük a kilencvenes években a horvát diaszpóra mobilizációját és annak politikai következményeit, illetve azt, hogy a lengyel diaszpórapolitika kevésbé politizálódott át, és a belpolitikára nincs lényegi hatással, a két eset mégiscsak lényegileg különbözik egymástól. Ugyanígy azt sem mondhatjuk, hogy a leginkább (hol kül-, hol bel-) politikai célokat szolgáló román diaszpórapolitika egy tőről fakad akár a szlovén, akár a szerb példával. Végül a szlovák diaszpórapolitika visszafogottsága ugyan papírforma szerint közel állhatna a román vagy a szlovén példához, ebben az esetben viszont nem tekinthetünk el attól a ténytől, hogy a szlovák diaszpórapolitika jellemzői nagymértékben a magyar nemzetpolitikai lépésekre adott szlovák politikai reakciók eredményei. Konklúzióm tehát az, hogy noha rengeteg közös vonás található a közép-európai államok diaszpórapolitikáiban, nem lehet azokat az egyes országok sajátos helyzete, történelmi öröksége, belpolitikai szembenállásai vagy akár kényszerhelyzetei (például balkáni háborúk) figyelembevétele nélkül vizsgálni. A differenciáltabb vizsgálati fókusz viszont rávilágít ezeknek a diaszpórapolitikáknak a különbözőségeire, egyediségére.

Ha a gamleni tipológiában szeretnénk elhelyezni a közép-európai diaszpórapolitikákat, akkor többségük a jogkiterjesztő és a kapacitásépítő típusba sorolható be, hiszen az állampolgárság és a szavazati jog kiterjesztése (jogkiterjesztés) a szlovák esetet leszámítva mindenhol megjelenik, és minden esetben léteznek támogatási formák, valamint szimbolikus gesztusok (kapacitásépítés) a diaszpóra felé. Kötelezettségbehajtásra a horvát és a román eset lehet példa a diaszpóra szavazati potenciálja miatt, gazdasági vagy egyéb erőforráskiaknázásra egyelöre minden ország esetében csak tervek vannak. Azonban, csakúgy, mint a klasszikus 
diaszpórapolitikáknál, a közép-európaiaknál is időben változott az, hogy éppen melyik aspektus jellemezte erőteljesebben a diaszpórapolitikát. Éppen ezért az egyértelmű kategorizáció helyett (vagy mellett) érdemes a diaszpórapolitika történeti fejlödését, fontosabb fordulópontjait is figyelembe venni.

REGIO 26. évf. (2018) 3. szám 155-234. 


\begin{tabular}{|c|c|c|c|c|c|c|c|}
\hline $\begin{array}{l}\text { Típus } \\
\text { (Gamlen) }\end{array}$ & $\begin{array}{l}\text { Politikai } \\
\text { gyakorlat }\end{array}$ & Horvátország & Szerbia & Lengyelország & Románia & Szlovákia & Szlovénia \\
\hline \multirow[t]{2}{*}{ Kapacitás-építő } & $\begin{array}{l}\text { Szimbolikus } \\
\text { nemzetépítés }\end{array}$ & + & + & + & + & + & + \\
\hline & Intézmények & + & + & + & + & + & + \\
\hline \multirow[t]{3}{*}{ Jogkiterjesztő } & Állampolgárság & + & + & + & + & - & + \\
\hline & Szavazati jog & + & + & + & + & - & + \\
\hline & $\begin{array}{l}\text { Polgári és } \\
\text { szociális jogok }\end{array}$ & - & - & - & - & - & - \\
\hline \multirow[t]{3}{*}{$\begin{array}{l}\text { Kötelezettség- } \\
\text { behajtó }\end{array}$} & $\begin{array}{l}\text { Befektetés- } \\
\text { ösztönzés }\end{array}$ & - & $-*$ & - & $-*$ & - & - \\
\hline & Network & - & $-*$ & - & $-*$ & - & + \\
\hline & Lobbi & $\begin{array}{c}\text { '90-es } \\
\text { években volt } \\
\text { jellemző }\end{array}$ & - & - & - & - & - \\
\hline
\end{tabular}

REGIO 26. évf. (2018) 3. szám 155-234. 


\section{Felhasznált irodalom}

About EPIC Ireland | Dublin Docks Tourist Attraction, EPIC, http://epicchq.com/about-epic-irish-emigration-museum/. (Utolsó letöltés: 2017. október 26.)

Accetto, Matej: Access to Electoral Rights Slovenia. EUDO Citizenship Observatory Country Reports. Badia Fiesolana, Italy: European University Institute, 2013.

Anderson, Benedict: Imagined Communities: Reflections on the Origin and Spread of Nationalism. Verso, 1991.

Anderson, Benedict O'Gorman Richard - Kligman, Gail: LongDistance Nationalism: World Capitalism and the Rise of Identity Politics. Centre for Asian Studies Amsterdam, 1992.

Az Örmény Köztársaság Alkotmánya. http://www.parliament.am/parliament.php?id=constitution\&lang =eng (Utolsó letöltés: 2017. április 26.)

Badurashvili, Irina: Diaspora and Government: Cases of Ireland, Italy and Slovenia. In Promoting Well Managed Migration between The EU and Georgia. Tbilisi: Caucasus Institute for Peace, Democracy and Development, 2014.

Bauböck, Rainer: Stakeholder Citizenship and Transnational Political Participation. A Normative Evaluation of External Voting. Fordham Law Review, 75, 2007. 5.

Bauböck, Rainer: Expansive Citizenship: Voting beyond Territory and Membership," PS: Political Science and Politics, 38, 2005. 4. 683-687.

Beit Hatfutsot - The Museum of The Jewish People. In Tel Aviv | About, Beit Hatfutsot, https://www.bh.org.il/about-us/about-beithatfutsot/. (Utolsó letöltés: 2017. november 28.)

Ben-Gurion-Israel and the Diaspora - The Ben-Gurion Blaustein Agreement http://www.zionism-israel.com/hdoc/Ben-GurionBlaustein_Zionism_Diaspora.htm. (Utolsó letöltés: 2017. március 22.)

REGIO 26. évf. (2018) 3. szám 155-234. 
Brubaker, Rogers: The Manichean Myth: Rethinking the Distinction Between 'Civic' and 'Ethnic' Nationalism," In: Nation and National Identity: The European Experience in Perspective, ed. Hanspeter Kriesi et al., Zurich: Ruegger, 1995. 55-71.

Centre for Slovaks Abroad Founded in Bratislava. Spectator.sme.sk, October 31, 2016, https://spectator.sme.sk/c/20372025/centrefor-slovaks-abroad-founded-in-bratislava.html. (Utolsó letöltés: 2017. május 21.)

Cochrane, Feargal: Irish-America, the End of the IRA's Armed Struggle and the Utility of 'Soft Power. Journal of Peace Research, 44, 2007. 2. 215-231.

Croatia: Still Playing Same Broken Record to Diaspora." Croexpress.eu. http://www.croexpress.eu/vijest.php?vijest=5533. (Utolsó letöltés: 2017. május 16.)

Csergő, Zsuzsa - Goldgeir, James M.: Nationalist Strategies and European Integration. In: The Hungarian Status Law: Nation Building and/or Minority Protection, ed. Zoltán Kántor et al. Sapporo: Hokkaido University, Slavic Research Center, 2004.

Culic, Irina: From Restitution to Privileged Re-Naturalisation: The Expansive Politics of Dual Citizenship in Romania after 1989. Minority Studies, 16, 2013. 125-152. [Special Issue: Trends and Directions of Kin-State Policies in Europe and Across the Globe.]

Day of the Polish diaspora and Poles abroad, http://www.rzym.msz.gov.pl/en/news/day_of_the_polish_diaspor a_and_poles_abroad. (Utolsó letöltés: 2017. május 18.)

Délano, Alexandra - Alan Gamlen: Comparing and Theorizing State-diaspora Relations. Political Geography, 41. 2014. July, 43-53.

Diaspora - Partener Pentru Dezvoltarea Romaniei (Diaszpóra Partner Románia fejlesztésében)" (Ministerul Afacerilor Externe Departamentul Politici pentru Relaţia cu Românii de Pretutindeni, 2016), http://www.dprp.gov.ro/wpcontent/uploads/2016/11/viziune-29.11.2016-.pdf. 
Dufoix, Stéphane: From Nationals Abroad to 'Diaspora': The Rise and Progress of Extra-Territorial and Over-State Nations. Diaspora Studies, 4, 2011. 1-20.

Dumbrava, Costica: Access to Electoral Rights Romania. EUDO Citizenship Observatory Country Reports. Badia Fiesolana, Italy: European University Institute, 2013.

Emigration Today| | EMIGRE: Current Irish Emigration and Return UCC, https://www.ucc.ie/en/emigre/emigration/. (Utolsó letöltés: 2017. október 26.)

Fiń, Anna et al.:Views and Attitudes of the Polish Community and Poles Living Abroad on the Policy Towards Polish Expatriate Communities. Poznań: Institute for Western Affairs, 2013.

Gamlen, Alan: Diaspora Engagement Policies: What Are They, and What Kinds of States Use Them? Centre on Migration, Policy and Society, Working Paper No.32. University of Oxford, 2006.

Gamlen, Alan: The Emigration State and the Modern Geopolitical Imagination." Political Geography, 27, 2008. 8. 840-856.

Gamlen, Alan: Diaspora Institutions and Diaspora Governance. International Migration Review, 48, 2014. 1. 180-217.

Gans, Herbert J.: Symbolic Ethnicity: The Future of Ethnic Groups and Cultures in America," Ethnic and Racial Studies, 2, 1979. 1. $1-20$.

Gellner, Ernest: Nations and Nationalism. Cornell University Press, 2008.

Global Irish - Ireland's Diaspora Strategy (Department of Foreign Affairs and Trade, 2015).

https://www.dfa.ie/media/globalirish/global-irish-irelandsdiaspora-policy.pdf 17.o. (Utolsó letöltés: 2017. szeptember 5.)

Górny, Agata - Pudzianowska, Dorota: Country Report: Poland, EUDO Citizenship Observatory Country Reports. Badia Fiesolana, Italy: European University Institute, Revised and updated 2013.

REGIO 26. évf. (2018) 3. szám 155-234. 
Governments of Israel, https://www.knesset.gov.il/govt/eng/GovtByNumber_eng.asp?go $\mathrm{vt}=34$. (Utolsó letöltés: 2017. március 24.)

Gráda, Cormac Ó.: Ireland: A New Economic History, 1780-1939. Oxford: Clarendon Press, 1995.

Gregg, Heather S.: Divided They Conquer: The Success of Armenian Ethnic Lobbies in the United States. Inter-University Committee on International Migration, 2002.

Halász Iván: A külhoni lengyelek és Lengyelország „diaszpóra politikája. Regio, 2003/4. 120-141.

Halász Iván: Szlovákia, a külföldön élő szlovák állampolgárok és a határon túli szlovákok Kapcsolatai.” In Állampolgárság Európában, 2005. Europa Institut Budapest, 2005. http://www.europainstitut.hu/index.php/24-sonstiges/915allampolgarsag-halasz.

Herner-Kovács Eszter: Elméleti keretek a diaszpóra-politikák vizsgálatához. Kisebbségkutatás, 2015/2. 34-39.

Hobsbawm, E. J.: Nations and Nationalism since 1780: Programme, Myth, Reality. Cambridge University Press, 2012.

Hodge, Carole: The Serb Lobby in the United Kingdom. Donald W. Treadgold Papers no. 22. 1995.

International Organization for Migration. Developing a Road Map for Engaging Diasporas in Development. International Organization for Migration; Migration Policy Institute, 2012. https://gfmd.org/files/pfp/Diaspora_Handbook_17April2012.pdf.

Iordachi, Constantin: Citizenship and National Identity in Romania: A Historical Overview. Regio, 2002. 1. 3-34.

Itzigsohn, Jose: Immigration and the Boundaries of Citizenship: The Institutions of Immigrants' Political Transnationalism. International Migration Review, 34, 2000. 4. 1126-1154.

Kántor Zoltán - Pászkán Zsolt: A határon túli románok és a románok státusztörvényei. Pro Minoritate, 2011. Tavasz, 70-81.

REGIO 26. évf. (2018) 3. szám 155-234. 
Kennedy, Liam - Lyes, Madeleine - Russell, Martin: Supporting the Next Generation of the Irish Diaspora, Report of a Research Project Funded by the Emigrant Support Programme, Department of Foreign Affairs and Trade. Dublin: Clinton Institute, University College Dublin, 2014.

Keogh, Dermot - O'Shea, Finbarr - Quinlan, Carmel (eds.): The Lost Decade. Ireland in the 1950s. Cork: Mercier Press, 2004.

Kiss Ágnes: Románia határon túli románságpolitikája az 1990-2004 között hatályos jogszabályok tükrében. Magyar Kisebbség, 2005/ 1-2. 298-353.

Koinova, Maria: Conditions and Timing of Moderate and Radical Diaspora Mobilization: Evidence from Conflict-Generated Diasporas. Global Migration and Transnational Politics Working Paper, 2009, no. 9.

Koinova, Maria: Conflict and Cooperation in Armenian Diaspora Mobilisation for Genocide Recognition. In: Diaspora as Cultures of Cooperation, edited by David Carment and Ariane Sadjed, Springer International Publishing, 2017. 111-129.

Korzec, Piotr - Pudzianowska, Dorota: Access to Electoral Rights Poland, EUDO Citizenship Observatory Country Reports. Badia Fiesolana, Italy: European University Institute, Revised and updated 2013.

Koska, Viktor: The Development of Kin-State Policies and the Croatian Citizenship Regime. Minority Studies 16, no. Special Issue: Trends and Directions of Kin-State Policies in Europe and Across the Globe, 2013. 214-230.

Kusa, Dagmar: The Slovak Question and the Slovak Answer. In: Bauböck, Rainer - Perchinig, Bernhard - Sievers, Wiebke (eds.): Citizenship Policies in the New Europe. Amsterdam: University Press, 2009.

Laguerre, Michel S.: Parliament and Diaspora in Europe. Europe in Transition: The NYU European Studies Series. New York: Palgrave Macmillan, 2013.

REGIO 26. évf. (2018) 3. szám 155-234. 
Lainer-Vos, Dan: Manufacturing National Attachments: Gift-Giving, Market Exchange and the Construction of Irish and Zionist Diaspora Bonds. Theory and Society, 41, 2012. 1. 73-106.

Lewitt, Peggy - Dehesa, Rafael de la: Transnational Migration and the Redefinition of the State: Variations and Explanations. Ethnic and Racial Studies, 26, 2003/4. 587-611.

Lieblich, André - Bauböck, Rainer: Is There (Still) an East-West Divide in the Conception of Citizenship in Europe? Working Paper, 2010.

Medved, Felicita: 'Unified Slovenian Nation': Slovenian Citizenship Policy towards Slovenians Abroad. Minority Studies, 16., 2013. 153-187. [Special Issue: Trends and Directions of Kin-State Policies in Europe and Across the Globe]

Migration in Serbia: A Country Profile, Migration in the Black Sea Region: Regional Overview. Country Profiles and Policy Recommendations. International Organization for Migration, 2008 .

Nairn, Tom: Faces of Nationalism: Janus Revisited. Verso, 1997.

Østergaard-Nielsen, Eva, ed. International Migration and Sending Countries: Perceptions, Policies and Transnational Relations. 2003 edition. Houndmills, Basingstoke, Hampshire; New York: Palgrave Macmillan, 2003.

Panossian, Razmik: Between Ambivalence and Intrusion: Politics and Identity in Armenia-Diaspora Relations. Diaspora: A Journal of Transnational Studies, 7, 1998/2. 149-96.

Pogonyi Szabolcs: Four Patterns of Non-Resident Voting Rights. Ethnopolitics, 13, 2014. 122-40.

Poland overtakes India as country of origin, UK Migration statistics show. BBC News, August 25, 2016, UK Politics,

Policy Forum Armenia: Armenia - Diaspora Relations: 20 Years Since Independence. Policy Forum Armenia, 2010.

Puskás, Julianna: Migráció Kelet-Közép-Európában a 19. és 20. században. Regio, 1991/4. 22-48.

REGIO 26. évf. (2018) 3. szám 155-234. 
Ragazzi, Francesco: A Comparative Analysis of Diaspora Policies. Political Geography 41. 2014.

Rava, Nenad: Country Report: Serbia, EUDO Citizenship Observatory Country Reports, CITSEE. Badia Fiesolana, Italy: European University Institute, Revised and updated 2013.

Safran, William: Diasporas in Modern Societies: Myths of Homeland and Return. Diaspora: A Journal of Transnational Studies 1, 1991. 1. 83-99.

Safran, William: Israel and the Diaspora. Problems of Cognitive Dissonance. IMI Working Papers Series No. 53, Oxford Diasporas Programme. International Migration Institute, Oxford University, 2012.

Saxe, Leonard - Chazan, Barry: Ten Days of Birthright Israel: A Journey in Young Adult Identity. Waltham, Mass: Hanover: Brandeis, 2008.

Saxe, Leonard et al. : Jewish Futures Project. The Impact of TaglitBirthright Israel: Marriage and Family. Brandeis University, Maurice and Marilyn Cohen Center for Modern Jewish Studies, 2014.

Sheffer, Gabriel: A Nation and Its Diaspora: A Re-Examination of Israeli-Jewish Diaspora Relations. Diaspora: A Journal of Transnational Studies, 11, 2011/3. 331-358.

Smith, Anthony D.: Nationalism and Modernism. London: Routledge, 1998.

Smith, Anthony D.: Diasporas and the Homelands in History: The Case of the Classic Diasporas, In: Gal, Allon - Leoussi, Athena S. - Smith, Anthony D. (eds.): The Call of the Homeland: Diaspora Nationalisms, Past and Present, Leiden, Boston: Brill, 2010.

Soltész Béla: Migráció és fejlesztő diaszpórapolitikák LatinAmerikában. PhD disszertáció, Budapesti Corvinus Egyetem, 2016.

REGIO 26. évf. (2018) 3. szám 155-234. 
STRATEGIA PRIVIND RELAŢIA CU ROMÂNII DE PRETUTINDENI 2013-2016 (A világszerte élő románokkal való kapcsolattartásra irányuló stratégia 2013-2016)" (Ministerul Afacerilor Externe Departamentul Politici pentru Relaţia cu Românii de Pretutindeni, 2013), http://www.dprp.gov.ro/wpcontent/uploads/2014/03/Strategie-2013.pdf.

The Diaspora, http://www.jewishvirtuallibrary.org/the-diaspora. (Utolsó letöltés: 2017. október 25.)

Tiwari, Smita: Diaspora Engagement Policy in South Asia. In: Yong, Tan Tai - Rahman, Md Mizanur: Diaspora Engagement and Development in South Asia, International Political Economy Series. Palgrave Macmillan UK, 2013, 212-230.

Tóth Pál Péter. "Nemzetközi vándorlás - Magyarország (19902000)." Népesedési Kormánybizottság Migrációs Bizottsága 2002. programja, KSH Népességtudományi Kutatóintézet. http://kisebbsegkutato.tk.mta.hu/kettosallampolgarsag/tanulmany ok/nemzetkozivandorlas_mo.pdf

Valentinčič, Dejan: Slovenia's Attitude Towards Slovenian Minorities in Neighbouring Countries. European Perspectives Journal on European Perspectives of the Western Balkans 6, 2014. 2. 63-83.

Voting from Abroad: The International IDEA Handbook, 2007. http://www.idea.int/publications/voting_from_abroad/index.cfm.

What Is the Neturei Karta? http://www.nkusa.org/aboutus/ (Utolsó letöltés: 2017. október 25.)

Winland, Daphne N.: We Are Now a Nation: Croats between "Home" and "Homeland. Anthropological Horizons, Toronto; Buffalo: University of Toronto Press, 2007.

Winland, Daphne N.: Contingent Selves: The Croatian Diaspora and the Politics of Desire. Revija Za Sociologiju XXIX, 1998. 1-2. 47-57.

Zarifian, Julien: The Armenian-American Lobby and Its Impact on U.S. Foreign Policy. Society, 51, 2014/5. 503-512.

REGIO 26. évf. (2018) 3. szám 155-234. 